\title{
Root canal preparation using micro-computed tomography analysis: a literature review
}

\begin{abstract}
Manoel Damião de SOUSA-NETO(a) Yara Correa SILVA-SOUSA(b) Jardel Francisco MAZZI-CHAVES(c) Kleber Kildare Teodoro CARVALHO(a) Ana Flávia Simões BARBOSA ${ }^{(b)}$ Marco Aurélio VERSIANI(a) Reinhilde JACOBS(c) Graziela Bianchi LEONI(b)
\end{abstract}

(a) Universidade de São Paulo, School of Dentistry of Ribeirão Preto, Department of Restorative Dentistry, Ribeirão Preto, SP, Brazil;

(b) Universidade de Ribeirão Preto, Faculty of Dentistry, Ribeirão Preto, SP, Brazil.

(c) Katholieke Universiteit Leuven, Faculty of Medicine, Department of Imaging and Pathology, Leuven, Belgium.

Declaration of Interests: The authors certify that they have no commercial or associative interest that represents a conflict of interest in connection with the manuscript.

Corresponding Author: Manoel Damião de Sousa-Neto E-mail:sousanet@forp.usp.br

https://doi.org/10.1590/1807-3107bor-2018.vol32.0066

Submitted: May 03, 2018

Accepted for publication: May 29, 2018

Last revision: June 06, 2018
Abstract: This literature review has critically analyzed the published research related to the biomechanical preparation of root canals with three-dimensional analysis using micro-computed tomography (micro-CT). In December 2017, six databases (PubMed, Cochrane, Web of Science, Embase, Scopus, and Science Direct) were accessed using keywords to find articles including the use of the micro-CT analysis in biomechanical root canal preparation. There were 60 full articles that were selected, which were screened and read by two authors. The research that was reviewed and analyzed included root canal anatomy and sample selection, changes in canal shape and untouched canal areas, canal transportation and centering ability, and kinematics (motion). Of the studies selected, $49.18 \%$ discussed anatomical characteristics, with $54.1 \%$ of these studies describing mesial roots of mandibular molars with moderate curvature. Only 35\% used a stratified distribution based on root canal system morphology and quantitative data obtained by micro-CT. The analysis of canal transportation and centering ability showed that transport values in the apical third exceeded the critical limit of $0.3 \mathrm{~mm}$ in mesial roots of mandibular molars with moderate curvature, especially in the groups in which a reciprocating system was used. In relation to kinematics, $91.70 \%$ of the reviewed studies evaluated continuous rotating instruments, followed by reciprocating rotation $(38.33 \%)$, vibratory $(15 \%)$, and the adaptive kinematics, which was in only $8.33 \%$. The reciprocating kinematics was associated with higher canal decentralization and transportation indexes, as well as a greater capacity for dentin removal and debris accumulation. This literature review showed that the anatomy, the type of design and kinematics of instruments, and the experimental design are factors that directly influence the quality of biomechanical preparation of root canals analyzed in a qualitative and quantitative manner by micro-CT.

Keywords: Endodontics; Root Canal Preparation; X-Ray Microtomography.

\section{Introduction}

Biomechanical root canal preparation is an important endodontic treatment step. The goal is the complete removal of remaining pulp tissue, microorganisms, and infected dentin; as well as shaping of the root canal system (RCS) through 
the mechanical action of endodontic instruments and the chemical action of auxiliary solutions providing adequate conditions for the sealing of the pulp cavity and repair of the periapical tissues. . $^{1,3,4,5}$

Since 2012, new protocols for biomechanical root canal preparation have been developed using nickeltitanium (NiTi) instruments, whose flexibility and resistance to torsion allow their use in a continuous rotating movement; these in turn reduce the working time, operator fatigue, and the risk of operative accidents. . $^{6,8,9,9,10,11,12,13,14,15} \mathrm{NiTi}$ instruments have been developed with various geometric conformations, ${ }^{8}$ with the most significant design difference being the taper with conicity ranging from $2 \%$ to $12 \%$, compared to the standard $2 \%$ taper of stainless steel instruments established by ANSI/ADA in 1976 and updated in $1982 .{ }^{8}$

NiTi rotary instruments were first commercialized in the 1990s, and since then about 700 studies have been published in journals indexed in PubMed before June 2010. They have evaluated the performance of these instruments, as well as the newly developed instrument designs. Studies have shown that despite the flexibility, torsional strength, and elastic memory of NiTi instruments, they still leave a significant percentage of the canal surface untouched. This is mainly due to the anatomical characteristics of root canals, such as flattening, curvatures, isthmuses, recesses, and ramifications, which hinder the performance of the instrument and may leave tissue and bacterial remnants ${ }^{16,17,18,19,20,21,22,23}$ (Figure 1).

Another concern noted when NiTi rotary instruments first appeared was a screw effect, which added to the difficulty of preparing challenging anatomical areas. This led to the development of more than 150 mechanized systems with differing designs, including variable tapers as well as different alloy treatments and movement types. $2,8,24,25,26,27,28,29,30$

In this review, various mechanical systems have been reviewed and discussed according to the innovations in the design, type of alloy treatment, movements, and concept of recommended preparation, without commercial bias (Table 1). It is noted that some systems may incorporate more than one of the mentioned characteristics.

An attempt to overcome the limitations imposed by the anatomical complexity of the RCS resulted in the development of the Self-Adjusting File (SAF) instrument (Redent-Nova Inc., Ra'anana, Israel) with an innovative manufacturing process. It is an instrument with a distinctive design that features a hollow, compressible, thin-walled body, composed of a delicate NiTi trellis covered by an abrasive layer. The use of this single instrument allows its adaptation inside the root canal, and by its vibratory movement ( 3000 to 5000 vibrations per minute) of low amplitude $(0.4 \mathrm{~mm})$, it promotes uniform dentine wear, which results in a canal with a cross section similar to the original but with slightly larger dimensions. , $29,30,31,32,33,34,35$

Several reciprocating systems have been released ${ }^{26}$ such as Waveone (Dentsply Maillefer, Baillagues, Switzerland) and Reciproc (VDW GmbH, Munich, Germany), which are based on the concept of root canal preparation with a single instrument. These instruments are manufactured with a M-Wire alloy from a thermal treating process of the NiTi alloy,
A

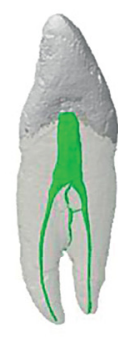

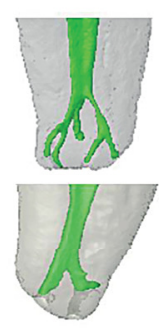

B

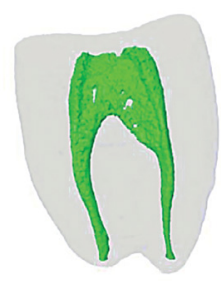

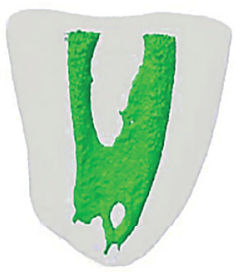

C

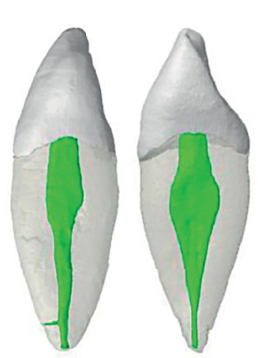

D

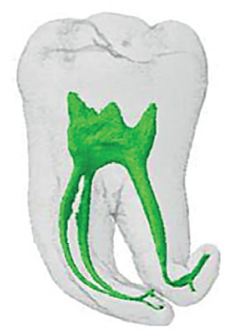

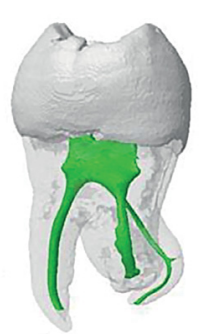

Figure 1. Three-dimensional models of root canal system of human teeth obtained from microcomputed tomography scanning showing the importance of the diagnosis of anatomical challenges prior to the biomechanical preparation of the root canal system. (A) Presence of accessory and lateral canals, and apical deltas. (B) Isthmus. (C) Flattened canals. (D) Presence of moderate and severe curvatures. 
Table 1. Mechanized systems cited in the reviewed studies according to the kinematics and alloys treatment used in their manufacture.

\begin{tabular}{|c|c|c|}
\hline \multirow{2}{*}{ Kinematics } & \multicolumn{2}{|c|}{ Alloy type } \\
\hline & NiTi with no treatment & NiTi with treatment \\
\hline \multirow{18}{*}{ Continous } & BioRace (FKG Dentaire) & HyFlex CM (Coltene) \\
\hline & Hero (Micro-Mega) & K3XF (SybronEndo) \\
\hline & Hyflex (Coltene) & OneShape (Micro Mega) \\
\hline & K3 (SybronEndo) & ProTaper Gold (Dentsply) \\
\hline & Mtwo (VDW) & TRUShape (Dentsply) \\
\hline & ProTaper Next (Dentsply) & Vortex Blue (Dentsply) \\
\hline & ProTaper Universal (Dentsply) & XP-endo Shaper (FKG Dentaire) \\
\hline & Revo-S (Micro-Mega) & XP-endo Finisher (FKG Dentaire) \\
\hline & EdgeFile (EdgeEndo) & Twisted File (SybronEndo) \\
\hline & iRaCe (FKG Dentaire) & $\mathrm{RaCe}$ (FKG Dentaire) \\
\hline & FlexMaster (VDW) & ProGlider (Dentsply) \\
\hline & System GT (Dentsply) & ScoutRace (FKG Dentaire) \\
\hline & Profile (Dentsply) & Ease ProDesign Logic (Easy) \\
\hline & GT Rotary File (Dentsply) & HyFlex EDM (Coltene) \\
\hline & EndoSequence (Brasseler) & BT Race (FKG Dentaire) \\
\hline & EndoEZE AET (Ultradent) & - \\
\hline & Vortex (Dentsply) & - \\
\hline & Wizard Navigator (Medin) & - \\
\hline \multirow{3}{*}{ Reciprocating } & Reciproc (VDW) & \\
\hline & WaveOne (Dentsply) & Reciproc Blue (VDW) \\
\hline & EZ-Fill Safesider system (EDS) & \\
\hline Adaptative & - & Twisted File Adaptive (SybronEndo) \\
\hline Vibratory & Self-Adjusting File (ReDent-Nova) & - \\
\hline
\end{tabular}

which provides greater flexibility and resistance to cyclic fatigue than the conventional NiTi alloy. ${ }^{4,9,11,13,}$ 15,33,34,35,36,37,38,39,40,41,42,43,44,45 The movement dynamics of these instruments, known as reciprocating, is the rotation in the counterclockwise direction (cutting direction) followed by a less extensive clockwise rotation (instrument releasing direction), facilitating continuous and progressive movement toward apical. ${ }^{15,26}$ According to some authors, the reciprocating movement reduces the risk of torsion fracture because the instrument is not subjected to the stress levels caused by a continuous rotary motion. $15,26,46,47,48$

Another system for the preparation of the root canal based on the concept of a single instrument, but with continuous rotation, is the OneShape system (MicroMega, Besançon, France). ${ }^{11,49,50}$ This system is produced from conventional NiTi alloy using a tip diameter of \#25 and continuous 0.06 taper, with three different cross-sections along the active part, variable pitch, and idle spirals, with the goal of reducing the tapping effect. ${ }^{11,50,51,52}$ This was also a goal for several other systems, including Race (FKG Dentaire S.A., La Chaux-de-Fonds, Switzerland), Rondo (FKG Dentaire S.A., La Chaux-de-Fonds, Switzerland), EndoSequence (Brasseler USA Dental, Savannah, USA), and EndoWave (J. Morita Corporation, Osaka, Japan), which presented a design of helical angles and alternating areas and, more recently, systems including BioRace (FKG Dentaire S.A., La Chaux-de-Fonds, Switzerland), Revo-S (MicroMega, Besançon, France) and ProTaper Next (Dentsply Maillefer, Ballaigues, Switzerland).

With a combination of continuous and reciprocating motions, the Twisted File Adaptive system was developed (SybronEndo, Orange, USA) with instruments made from a phase- $\mathrm{R}$ thermal treatment alloy that adapted the kinematics to the stress of the 
instrumentation. This system was designed to permit switching from a continuous clockwise motion (when the instrument is not subjected to stress within the canal) to an interrupted reciprocation motion (when undue tensions are generated by dentin) during instrumentation. ${ }^{37,44,45,47,53,54,55,56,57,58}$

There are also instruments designed with center of mass and/or center of rotation in offset that, in rotation, produce a mechanical wave that runs through the active part of the instrument. This results in improvement of the flexibility along the active part of the instrument and minimizes the instrument locking in the dentin, in addition to reducing the formation of debris. ${ }^{8,30,34,41,59}$ These features were incorporated into additional systems including Protaper Next (Dentsply Maillefer, Ballaigues, Switzerland), TRUShape (Dentsply Tulsa Dental Specialties, Tulsa, USA), Revo-S (Micro-Mega, Besançon, France), and One Shape (Micro-Mega, Besançon, France).

Recently, the concept of mechanical finalization of the biomechanical preparation was proposed. Following the mechanical preparation of the root canal, the instrument whips against the walls of the root canal allowing its action in untouched areas such as isthmuses, flattenings, and recesses. This action is possible with the XP-endo Finisher instrument (FKG Dentaire S.A., La Chaux-de-Fonds, Switzerland), which is produced with highly flexible NiTi MaxWire alloy (25/.00) (MartensiteAustenite Electropolish-FleX) that changes shape at different temperatures. The instrument is straight in the martensite phase (M-phase) of the alloy, which is reached when it is cooled, and when it is exposed to higher temperatures (such as body temperature) its shape changes due to molecular memory of the alloy to the austenite phase (A-phase). This makes the instrument assume a semi-circular conformation that, in rotation, allows it to reach an area of $6 \mathrm{~mm}$ in diameter that is 100 times greater than that of other instruments. ${ }^{60,61} \mathrm{In}$ 2017, Leoni et al. ${ }^{61}$ evaluated the possibility of using the XP-endo Finisher instrument as well as the SAF in the mechanical finishing of root canal preparation with isthmuses, demonstrating the reduction of accumulated debris after biomechanical preparation.

Later, with the combination of this NiTi MaxWire alloy and Booster Tip technology, the XP-endo Shaper (FKG Dentaire S.A., La Chaux-de-Fonds, Switzerland) offered greater flexibility, fatigue resistance, and penetration of the canals with ease and speed, expanding or contracting according to canal morphology and preserving the three-dimensional structure of the root canal. ${ }^{62,63}$ Similar to the preparation finalization instrument mentioned above, this instrument can react to temperature variations and acquires a predetermined shape at body temperature, with the taper of the instrument starting at 01 and reaching a minimum .04 taper when it expands into the root canal. The Booster Tip has unique geometry that allows the operator to start the preparation after an initial glide path of at least ISO diameter 15, increasing its working range gradually until reaching ISO diameter 30, following the original canal path..$^{29,62}$

In addition to the aforementioned innovations, the thermomechanical treatment process of the alloys used in the fabrication of these instruments alters the molecular structure of the alloy, providing resistance to cyclic fatigue and flexibility while reducing shape memory, allowing pre-bending of the alloys. ${ }^{28,62,64,65,66}$ Use of this enhanced treatment process resulted in the development of blue rotary files. ${ }^{28}$ The Vortex Blue system (Dentsply Tulsa Dental Specialties, Tulsa, USA) and, more recently, the Reciproc Blue system (VDW GmbH, Munich, Germany) are features in a reciprocating kinematics.

Parallel to the development of mechanized instruments and systems for clinical use, experimental models for the evaluation of the biomechanical preparation of the RCS in human teeth were perfected. In previously available experimental models, biomechanical preparation was assessed by radiographic images $67,68,69,70$ and root cutting series using the muffle system or its variations; ${ }^{71,72}$ however, these methods allowed only a two-dimensional quantitative evaluation after preparation, and the muffle system was destructive. ${ }^{73,74,75}$

A solution for the three-dimensional and nondestructive evaluation of the RCS appears to be the use of computed tomography and magnetic resonance imaging in experimental procedures. $27,76,77,78$ The development of micro-CT allows a more precise RCS evaluation than a conventional CT scanner, and more recent use of specific software has made it possible to accurately assess the biomechanical 
preparation as well as the anatomy, root canal filling, and retreatment. ${ }^{2,3,4,5,7,79,11,12,13,14,15,25,27,28,29,30,31,34,35,37,38,39,40,41,42,}$ $43,44,45,47,56,57,58,59,61,62,63,68,79,80,81,82,83,84,85,86,87,88,89,90,91,92,93,94,95,96,97$, $98,99,100,101,102,103,104,105,106,107,108,109$

The aim of this review is to present a discussion of the studies that evaluated the preparation of root canals by three-dimensional analysis based on the use of micro-CT while considering the evolution of NiTi instruments and biomechanical preparation evaluation methods, as well as the limitations imposed by the anatomical aspects of the RCS and the resulting need for sample selection for biomechanical preparation evaluation studies. The topics that will be addressed include root canal anatomy and sample selection, changes in canal shape and untouched canal areas, canal transportation and centering ability, and kinematics (motion).

\section{Methodology}

This literature review followed the PRISMA (Preferred Reporting Items for Systematic Reviews and Meta-Analyses) guidelines for literature review to ensure the understanding, transparency, and fidelity of the results..$^{110,111}$

The search strategy was used in six databases (PubMed, Cochrane, Web of Science, Embase, Scopus, and Science Direct), with the same key word combinations and MeSH Terms (Table 2), including titles, abstracts, and full texts. The search was performed in December 2017, and there was no initial restriction regarding the year of publication, article language, or journal publication.

After the initial search, all of the titles and abstracts were screened by two authors to find eligible full articles to be included in the literature review.

The evaluation of the mechanized (rotary, reciprocating, oscillatory) biomechanical preparation of the RCS by micro-CT was the inclusion criteria used in the article selection. Furthermore, to reduce the risk of bias, it included only studies in the English language that evaluated mechanized endodontic systems, used human permanent teeth (any type of tooth groups and root canals), and analyzed twodimensional and three-dimensional parameters (canal transportation, centering ability, changes in the volume, surface area, perimeter and area, and others) of the root canals before and after the biomechanical preparation.

Studies written in a language other than English; those which used endodontic hand files, deciduous teeth, acrylic/resin blocks with simulated root canals; and other types of analyses that did not include biomechanical preparation assessment were all excluded from the literature review. All studies found in the search were individually evaluated by two evaluators, and only after full agreement were they included in our study.

\section{Search results}

Initially using only titles and abstracts, a total of 102 articles were selected in the database search, and were saved in the Mendeley Reference Management Software \& Researcher Network to organize and subsequently facilitate the search and reading of articles. The articles did not meet inclusion criteria for various reasons such as articles that duplicated research or were not accessible in English or that used different methodologies, samples, or analysis are presented in the Table 3.

Only 60 papers met all inclusion criteria and were included in this literature review for 2003 to 2017 (Figure 2; Table 4).

\section{Antomical aspects that influence the sample selection and biomechanical preparation in studies in vitro}

The study of the internal anatomy of human teeth only aroused the interest of researchers at the end of the 19th century. In 1901, Preiwerk ${ }^{112}$ conducted the first studies with the injection of molten metal inside human dental canals. In 1913, Prinz ${ }^{113}$ developed the traditional diaphanization method, which was then used by Okumura (1927), ${ }^{114}$ a pioneer in the classification of root canals based on their anatomical characteristics. Through diaphanization, Vertucci $(1984)^{115}$ also classified the RCS of permanent human teeth into eight morphological types according to the number of canals and the location of their divisions in the same root, and this classification system was most commonly cited in the studies of internal anatomy. 
Table 2. The search strategy using during the literature review.

\begin{tabular}{|c|c|}
\hline Base & Strategy \\
\hline PubMed & $\begin{array}{l}\text { ("x-ray microtomography"[MeSH Terms] OR ("x-ray"[All Fields] AND "microtomography"[All Fields]) OR "x-ray } \\
\text { microtomography"[All Fields] OR "microct"[All Fields]) AND ("dental pulp cavity"[MeSH Terms] OR ("dental"[All Fields] AND } \\
\text { "pulp"[All Fields] AND "cavity"[All Fields]) OR "dental pulp cavity"[All Fields] OR ("root"[All Fields] AND "canal"[All Fields]) OR } \\
\text { "root canal"[All Fields]) }\end{array}$ \\
\hline $\begin{array}{l}\text { Cochrane } \\
\text { Central }\end{array}$ & $\begin{array}{l}\text { ("x-ray microtomography"[MeSH Terms] OR ("x-ray"[All Fields] AND "microtomography"[All Fields]) OR "x-ray } \\
\text { microtomography"[All Fields] OR "microct"[All Fields]) AND ("dental pulp cavity"[MeSH Terms] OR ("dental"[All Fields] AND } \\
\text { "pulp"[All Fields] AND "cavity"[All Fields]) OR "dental pulp cavity"[All Fields] OR ("root"[All Fields] AND "canal"[All Fields]) OR } \\
\text { "root canal"[All Fields]) AND biomechanical[All Fields] AND preparation[All Fields] }\end{array}$ \\
\hline $\begin{array}{l}\text { Web of } \\
\text { Science }\end{array}$ & $\begin{array}{l}\text { ("dental pulp cavity"[MeSH Terms] OR ("dental"[All Fields] AND "pulp"[All Fields] AND "cavity"[All Fields]) OR "dental pulp } \\
\text { cavity"[All Fields] OR ("root"[All Fields] AND "canal"[All Fields]) OR "root canal"[All Fields]) AND ("x-ray microtomography"[MeSH } \\
\text { Terms] OR ("x-ray"[All Fields] AND "microtomography"[All Fields]) OR "x-ray microtomography"[All Fields] OR } \\
\text { ("microcomputed"[All Fields] AND "tomography"[All Fields]) OR "microcomputed tomography"[All Fields]) }\end{array}$ \\
\hline Embase & $\begin{array}{l}\text { ("root canal preparation"[MeSH Terms] OR ("root"[All Fields] AND "canal"[All Fields] AND "preparation"[All Fields]) OR "root } \\
\text { canal preparation"[All Fields]) AND ("x-ray microtomography"[MeSH Terms] OR ("x-ray"[All Fields] AND "microtomography"[All } \\
\text { Fields]) OR "x-ray microtomography"[All Fields] OR ("microcomputed"[All Fields] AND "tomography"[All Fields]) OR } \\
\text { "microcomputed tomography"[All Fields]) }\end{array}$ \\
\hline Scopus & $\begin{array}{l}\text { ("root canal preparation"[MeSH Terms] OR ("root"[All Fields] AND "canal"[All Fields] AND "preparation"[All Fields]) OR "root } \\
\text { canal preparation"[All Fields]) AND ("x-ray microtomography"[MeSH Terms] OR ("x-ray"[All Fields] AND "microtomography"[All } \\
\text { Fields]) OR "x-ray microtomography"[All Fields] OR "microct"[All Fields]) }\end{array}$ \\
\hline \multirow{7}{*}{$\begin{array}{l}\text { Science } \\
\text { Direct }\end{array}$} & $\begin{array}{l}\text { ("root canal preparation"[MeSH Terms] OR ("root"[All Fields] AND "canal"[All Fields] AND "preparation"[All Fields]) OR "root } \\
\text { canal preparation"[All Fields]) AND ("x-ray microtomography"[MeSH Terms] OR ("x-ray"[All Fields] AND "microtomography"[All } \\
\text { Fields]) OR "x-ray microtomography"[All Fields] OR "microct"[All Fields]) AND ("evaluation studies"[Publication Type] OR } \\
\text { "evaluation studies as topic"[MeSH Terms] OR "evaluation"[All Fields]) }\end{array}$ \\
\hline & $\begin{array}{l}\text { ("root canal preparation"[MeSH Terms] OR ("root"[All Fields] AND "canal"[All Fields] AND "preparation"[All Fields]) OR "root } \\
\text { canal preparation"[All Fields]) AND ("x-ray microtomography"[MeSH Terms] OR ("x-ray"[All Fields] AND "microtomography"[All } \\
\text { Fields]) OR "x-ray microtomography"[All Fields] OR ("micro"[All Fields] AND "ct"[All Fields]) OR "micro ct"[All Fields]) AND } \\
\text { ("evaluation studies"[Publication Type] OR "evaluation studies as topic"[MeSH Terms] OR "evaluation"[All Fields]) }\end{array}$ \\
\hline & $\begin{array}{l}\text { ("root canal preparation"[MeSH Terms] OR ("root"[All Fields] AND "canal"[All Fields] AND "preparation"[All Fields]) OR "root } \\
\text { canal preparation"[All Fields]) AND ("x-ray microtomography"[MeSH Terms] OR ("x-ray"[All Fields] AND "microtomography"[All } \\
\text { Fields]) OR "x-ray microtomography"[All Fields] OR ("micro"[All Fields] AND "ct"[All Fields]) OR "micro ct"[All Fields]) }\end{array}$ \\
\hline & $\begin{array}{l}\text { ("root canal preparation"[MeSH Terms] OR ("root"[All Fields] AND "canal"[All Fields] AND "preparation"[All Fields]) OR "root } \\
\text { canal preparation"[All Fields]) AND ("x-ray microtomography"[MeSH Terms] OR ("x-ray"[All Fields] AND "microtomography"[All } \\
\text { Fields]) OR "x-ray microtomography"[All Fields] OR ("micro"[All Fields] AND "ct"[All Fields]) OR "micro ct"[All Fields]) AND } \\
\text { ("evaluation studies"[Publication Type] OR "evaluation studies as topic"[MeSH Terms] OR "evaluation"[All Fields]) }\end{array}$ \\
\hline & $\begin{array}{l}\text { ("root canal preparation"[MeSH Terms] OR ("root"[All Fields] AND "canal"[All Fields] AND "preparation"[All Fields]) OR } \\
\text { "root canal preparation"[All Fields]) AND micro-computed[All Fields] AND tomographic[All Fields] AND ("evaluation } \\
\text { studies"[Publication Type] OR "evaluation studies as topic"[MeSH Terms] OR "evaluation"[All Fields]) }\end{array}$ \\
\hline & $\begin{array}{l}\text { ("root canal preparation"[MeSH Terms] OR ("root"[All Fields] AND "canal"[All Fields] AND "preparation"[All Fields]) OR "root } \\
\text { canal preparation"[All Fields]) AND micro-computed[All Fields] AND tomographic[All Fields] }\end{array}$ \\
\hline & $\begin{array}{l}\text { ("root canal preparation"[MeSH Terms] OR ("root"[All Fields] AND "canal"[All Fields] AND "preparation"[All Fields]) OR } \\
\text { "root canal preparation"[All Fields]) AND micro-computed[All Fields] AND ("tomography, x-ray computed"[MeSH Terms] OR } \\
\text { ("tomography"[All Fields] AND "x-ray"[All Fields] AND "computed"[All Fields]) OR "x-ray computed tomography"[All Fields] OR } \\
\text { "tomography"[All Fields] OR "tomography"[MeSH Terms]) }\end{array}$ \\
\hline
\end{tabular}

Subsequently, other studies added more than 30 morphological types to this classification $33,116,17,118,119,120,121$ evidencing that a root with a conical canal and a single foramen was not commonplace. ${ }^{1}$

To increase the accuracy of the methods previously proposed for the evaluation of dental anatomy, the micro-CT allowed the non-destructive threedimensional analysis of additional canals, multiple foraminas, apical deltas, isthmuses, C-shaped roots and canals, and accessory canals $\mathrm{s}^{3,33,82,122,123}$ (Figure 1).
In addition, it obtained three-dimensional quantitative data of volume, surface area, and the structure model index (SMI); and two-dimensional parameters of area, perimeter, major and minor diameter, roundness and form factor of the root canal. 3,32,33,108,122,123,124,125

Obtaining these quantitative micro-CT anatomy data may have contributed to in vitro studies producing more reliable results from a more selective sample, with the formation of homogeneous groups for the degree of curvature, diameter, and internal morphology, 
Table 3. Articles excluded during the strategy search.

\begin{tabular}{|c|c|}
\hline Article & Exclusion reason \\
\hline Rhodes et al., 1999 & This study purposes the validation of the Micro-CT methodology. \\
\hline Rhodes et al., 2000 & This study used a manual/hand files. \\
\hline Peters et al., 2000 & This study evaluated only root canal anatomy. \\
\hline Peters; Schonenberger; Laib., 2001 & This study used a manual/hand files. \\
\hline Peters et al., 2001 & This study used a manual/hand files. \\
\hline Bergmans et al., 2001 & $\begin{array}{c}\text { This study purposes the validation of the Micro-CT methodology to evaluate the root canal } \\
\text { preparation. }\end{array}$ \\
\hline Hubscher; Barbakow; Peters., 2003 & This study did not evaluate biomechanical preparation by Micro-CT. \\
\hline Chen et al., 2009 & Article written in Chinese. \\
\hline Kim et al., 2009 & This study used simulated curved canals. \\
\hline Paqué; Ganahl; Peters., 2009 & This study used a manual/hand files. \\
\hline Moore; Fitz-Walter; Parashos., 2009 & This study used a manual/hand files. \\
\hline Metzger et al., 2010 & This study did not evaluate biomechanical preparation by Micro-CT. \\
\hline Yin et al., 2010 & This study used a manual/hand files. \\
\hline Paqué; Zehnder; Marending., 2010 & $\begin{array}{l}\text { This study used a manual/hand files and did not evaluate biomechanical preparation by } \\
\text { Micro-CT. }\end{array}$ \\
\hline Li et al., 2011 & This study used a manual/hand files. \\
\hline Ounsi et al., 2011 & This study used simulated curved canals. \\
\hline ElAyouti et al., 2011 & This study used a manual/hand files. \\
\hline Narayan et al., 2012 & This study did not evaluate biomechanical preparation by Micro-CT. \\
\hline Pasqualini et al., 2012 & This study did not evaluate biomechanical preparation. \\
\hline Marending; Schicht; Paqué., 2012 & This study did not evaluate biomechanical preparation. \\
\hline Markvart et al., 2012 & This study used a manual/hand files. \\
\hline Ametrano et al., 2013 & Article written in Italian. \\
\hline Stavileci et al., 2013 & This study used a manual/hand files. \\
\hline Ordinola-Zapata et al., 2014 & This study used prototyping teeth replicas. \\
\hline Zeng et al., 2014 & Article written in Chinese. \\
\hline Muhaxheri et al., 2015 & This study used a manual/hand files. \\
\hline Kirchhoff et al., 2015 & This study did not evaluate biomechanical preparation of the entire root canal. \\
\hline Liu \& Bulling., 2016 & This study used simulated canals in resin blocks. \\
\hline De-Deus et al., 2016 & This study did not evaluate biomechanical preparation only dentinal defects. \\
\hline Chen; Chen; Liang., 2016 & Article written in Chinese. \\
\hline Keles et al., 2016 & $\begin{array}{l}\text { This study did not evaluate biomechanical preparation only the reduction of accumulated hard } \\
\text { tissue debris after different irrigation protocols. }\end{array}$ \\
\hline Bayram et al., 2017 & This study did not evaluate biomechanical preparation only dentinal microcrack formation. \\
\hline Kaya; Elbay; Yigit, 2017 & This study used primary teeth. \\
\hline Zanesco et al., 2017 & This study used a manual/hand files. \\
\hline Cassimiro et al., 2017 & This study did not evaluate biomechanical preparation only dentinal defects. \\
\hline Amoroso-Silva et al., 2017 & This study used a manual/hand files. \\
\hline Alovisi et al., 2017 & This study used a manual/hand files. \\
\hline
\end{tabular}

which will result in a better understanding of the action of each instrument according to the internal anatomy of the RCS. In this way, we will next discuss the anatomical aspects that were used in the 60 studies included in our literature review.
In the studies we reviewed, teeth with immature apices, resorptive defects, fractured roots, or root canal fillings or obstructions were excluded. For inclusion, the mandibular molar was generally the dental group of choice in $60 \%(n=36)$ of the studies 


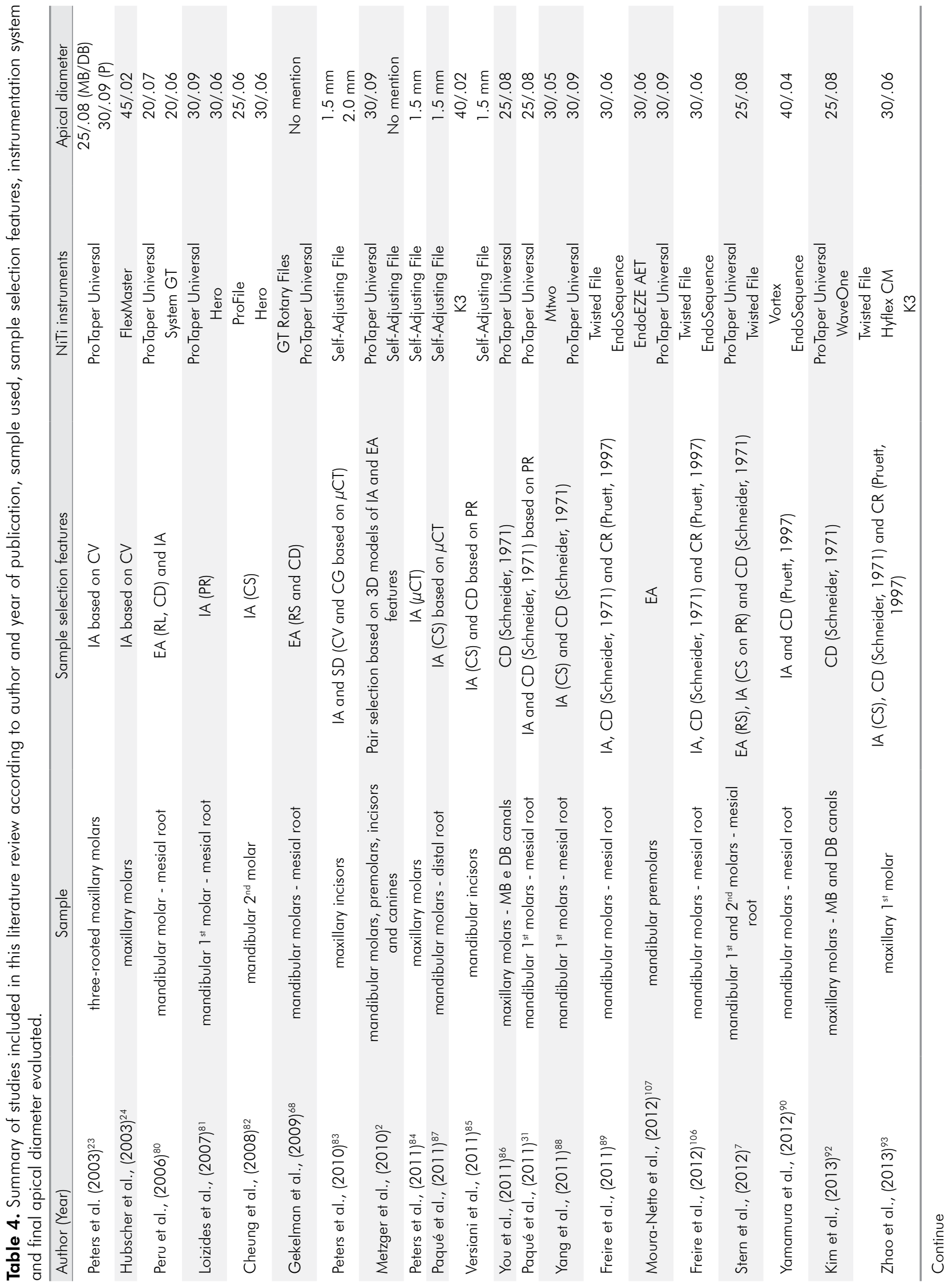




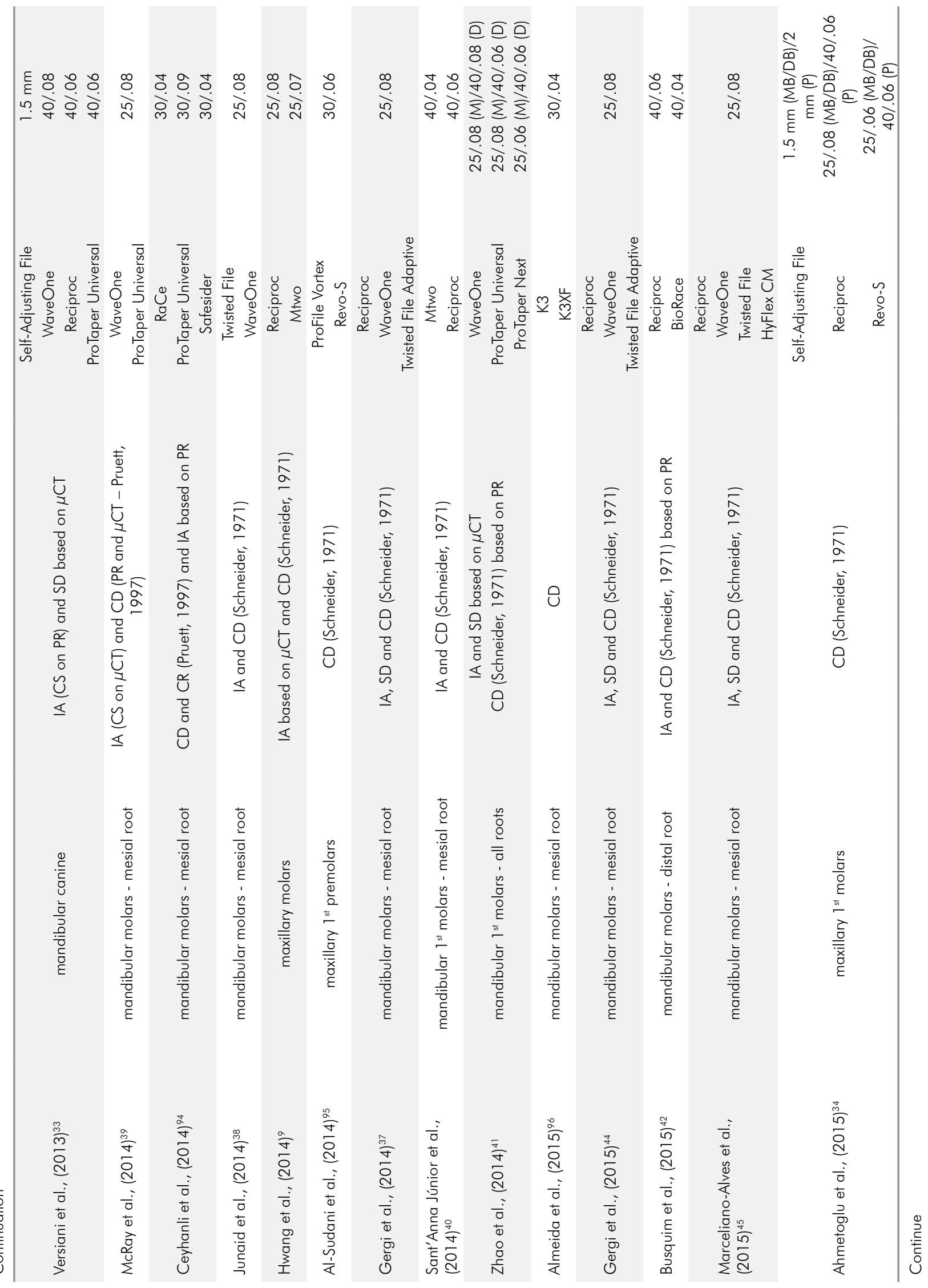




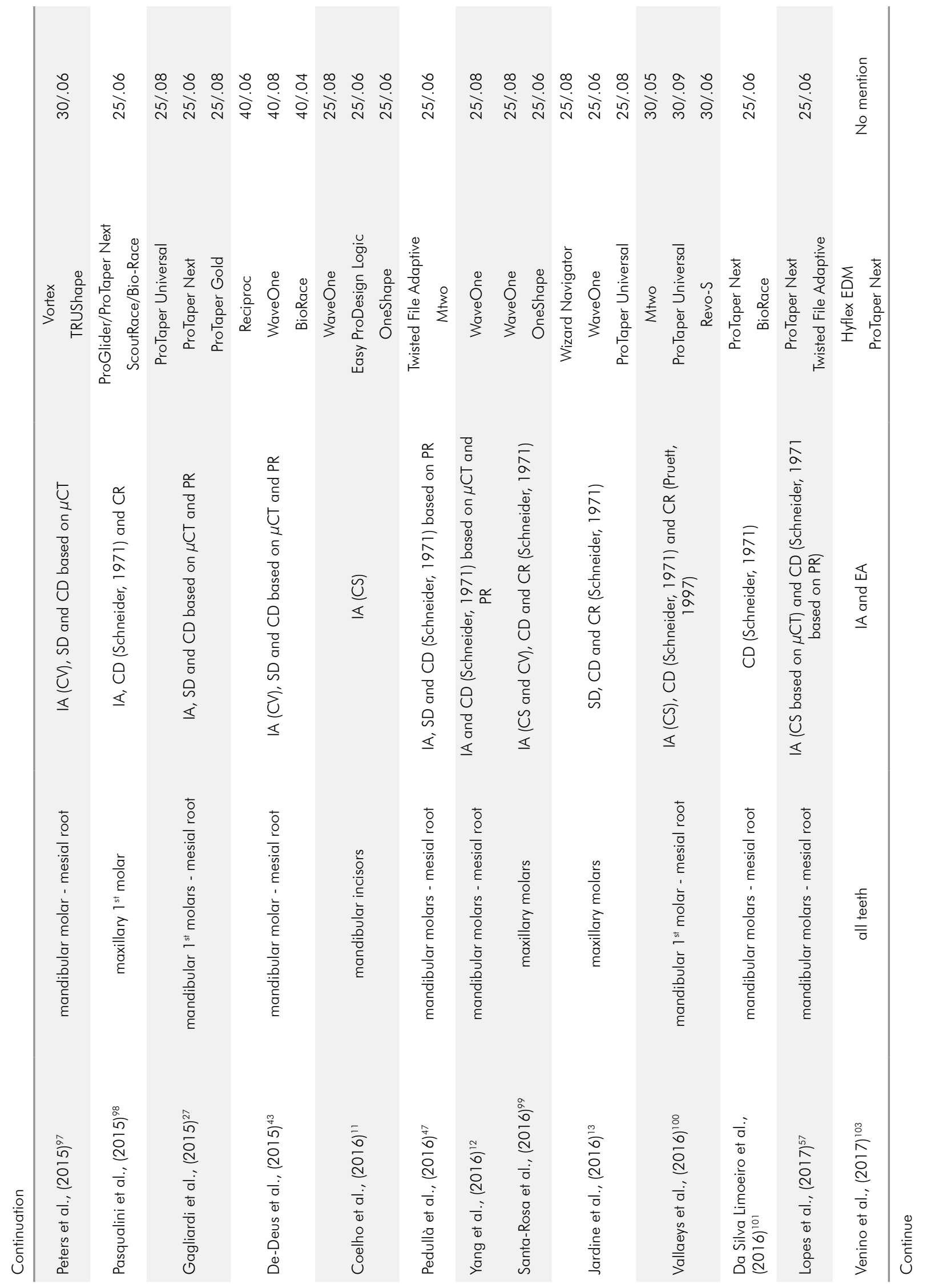




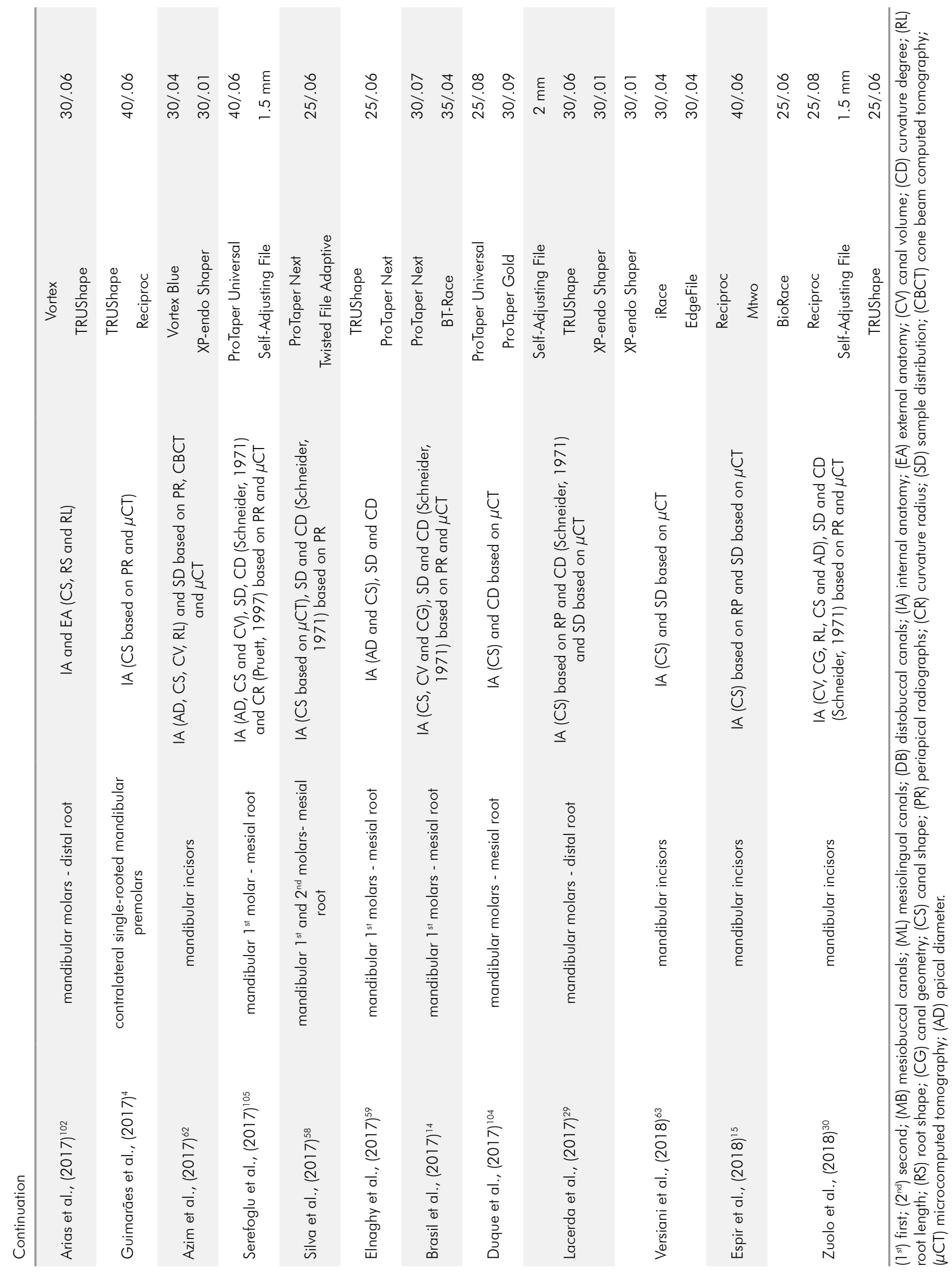




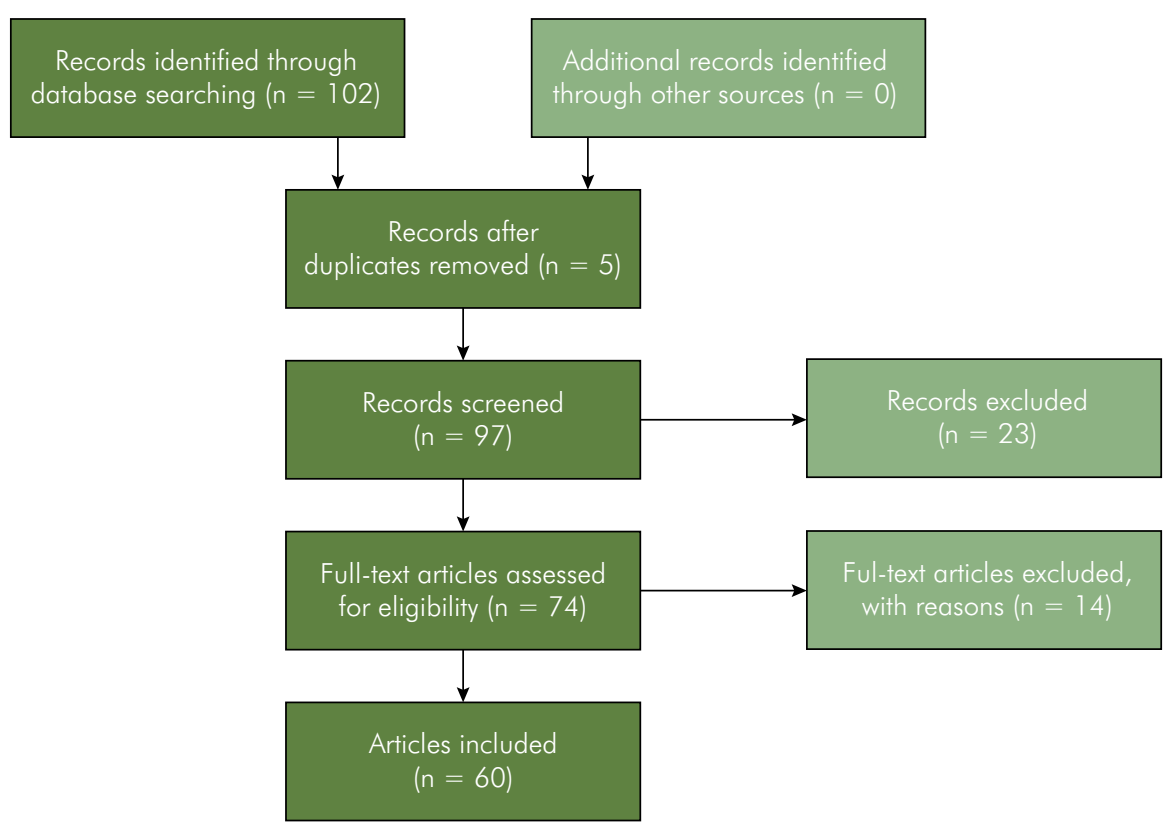

Figure 2. Flow diagram with the database search and articles include (based on PRISMA).

reviewed, and in $83.33 \%$ of those $(n=30)$ in which the mesial root was selected for the root canal preparation evaluation. The curvature of the selected roots was evaluated in $71.66 \%(n=43)$ of the studies with a higher prevalence of roots with moderate curvature and a bend angle between $20^{\circ}$ and $40^{\circ}$ in $58.13 \%(n=25)$. It is worth noting that the degree of curvature can influence the maintenance of the centering ability of the root canals. ${ }^{44,47}$

It was observed in the description of the methodologies that $50 \%(n=30)$ of the studies reported criteria of sample selection based on the internal anatomy of the root canals, qualitatively by Vertucci's classification; ; $1214,40,43,44,45,47,58,62,63,93,97,101,104,115$ isthmus classification; ${ }^{57,58}$ root canal shape, ${ }^{4,11,15,}$ $30,31,33,42,62,63,85,102$ anatomical variation; 82 and/or by quantitative composition of similar or homogeneous groups in relation to bi- and tri-dimensional parameters of the root canal. $13,14,15,29,30,33,37,41,43,44,45,47,5$ $7,58,59,62,63,83,105,126,127$ In view of this, a variation of the root canal anatomy selected in these studies was observed, which made it difficult to statistically compare the data obtained.

Regarding selection of the type of canal, Vertucci's classification for the evaluation of the root canal preparation showed the use of the Type I (single canal that extends from the pulp chamber to the apex) for incisors, ${ }^{62}$ Type II (two canals that leave the pulp chamber and join near the apex to form a single canal), ${ }^{43}$ and Type IV (two distinct and separate canals that extend from the pulp chamber to the apex) in mesial roots of mandibular molars. ${ }^{12,14,40,44,45,47,97,101,104}$ Also, in mesial roots of mandibular molars, isthmus classification Type I (narrow sheet and complete connection existing between two canals) ${ }^{128}$ or Type III (incomplete isthmus existing above or below a complete isthmus) ${ }^{57,58}$ was seen.

Another aspect of the internal anatomy used for the sample selection in the analyzed studies was the canal flattening, which classified the root canals as oval in $21.67 \%(n=13)$ of the studies rev iewed, ${ }^{11,15,29,30,33,45,62,102}$ long-oval ${ }^{31,42,63}$ and flat-oval ${ }^{85}$ in $53.84 \%(n=7)$ of these studies, evaluating the degree of flattening by means of the ratio between the buccolingual and mesiodistal dimensions of the root canal on radiographs $s^{15,29,30,33,42,85}$ and in CBCT images. ${ }^{11}$ The studies did not use quantitative data obtained by micro-CT (roundness, factor form, major and minor diameter, and SMI), which 
would have provided greater acuity of this type of anatomical variation.

Regarding the composition of the experimental groups, only $35 \%(n=21)$ of the studies used a stratified distribution proposed by Versiani et al. ${ }^{33}$ based on the similar internal anatomy and morphological dimensions of the root canal (statistically similar dimensions of the root canal) from the two-dimensional and three-dimensional data obtained by the micro-CT prior to the preparation. ${ }^{27,29,33,34,45,57,63,97,98}$

Because studies have shown that the result of the biomechanical preparation depends more on the original anatomy of the root canal than on the instrument or technique used,,$^{6,27,33,42,45,64,129,130,131,132}$ it becomes important to properly select samples with two-dimensional and three-dimensional values in order for the experimental groups to be balanced in terms of anatomical characteristics, which can improve the understanding of the results of each instrument against the different morphological characteristics of the root canals. ${ }^{33,63,129}$

\section{Changes in the canal geometrics and untouched areas after biomechanical preparation}

The action of mechanized instruments inside the RCS promotes dentin wear that results in changes in the geometric configuration of the root canal, and these can be qualitatively and quantitatively observed through micro- $\mathrm{CT}^{30,33,45,63}$ by images obtained at different steps in endodontic treatment by aligning the three-dimensional spatial coordinates of $\mathrm{x}, \mathrm{y}$, and $\mathrm{z}$ on specific software.

The quantitative parameters used for the evaluation of changes in the geometric configuration resulting from the biomechanical preparation are the three-dimensional parameters of volume, surface area, and (SMI); and two-dimensional parameters of area, perimeter, roundness, form factor, and major and minor diameter. ${ }^{32,33,43,45,63}$ The reviewed studies corroborate that after the biomechanical preparation, there is an increase in these parameters, regardless of the type of instrument or technique used. $4,27,36,41,44,47,102,104$

In addition, it is also possible to quantify the percentage of root canal walls touched and not touched by instruments. The touch or action of the instrument on the canal walls and the changes in volume and SMI are the parameters most used $(68.85 \%)$ to evaluate the preparation by means of micro-CT. ${ }^{4,11,15,42,47,57,62,83,96,102,103,105}$

The change in canal volume is related to the effects of biomechanical preparation on dentin removal, $7,25,44,83,132,133$ showing that the volume increase after preparation is proportionally higher in the cervical and middle third than in the apical and can be attributed to the cervical preparation ${ }^{7,32,33,84}$ and to the greater taper of the instruments in the cervical region. ${ }^{11,47}$ Clinically, the increase in canal volume in the cervical third can mean the improvement of the reach of irrigating solutions in the apical third, or that the apical mechanical debridement was not as effective as cervical ${ }^{7,12}$ (Figure 3).

An important aspect observed in this review was that $50 \%(n=30)$ of studies evaluated the average percentage of canal walls untouched after biomechanical preparation and showed that no system or technique was able to touch all the walls of root can als, $4,27,29,30,42,43,44,45,57$ showing a range of $2.6 \%$ to $80 \%$ of the walls being untouched. ${ }^{27,57}$ This variation may be related to changes in dental morphology, ${ }^{25,27,45,79,84,101,104}$ the characteristics of the instruments used, , , ,11,30,32,62,63,102 or the evaluation methodology used. ${ }^{25,31,84}$

In studies in which there was concern about sample selection, the percentage of untouched walls ranged from $8.17 \%$ to $58.8 \%$ for the whole canal in groups of teeth with flattened canals, ${ }^{62,63}$ and from $3.13 \%$ to $51.03 \%$ for the apical third. ${ }^{15,102}$

Another aspect that may explain the range in the percentage of untouched walls is the design variability of instruments such as taper, diameter, and cross-section. 4,11,30,32,62,102 The SAF, XP-endo Shaper, and TRUShape instruments showed highest percentages of touched walls when compared to other systems. ${ }^{4,29,30,31,32,33,63,102}$

Regarding the final diameter, the reviewed studies showed that the final diameter of the instruments used for the biomechanical preparation ranged from diameter 25 to diameter 40 with a diameter 30 being most common in these canals. The mesial canals of mandibular molars were the most frequently used sample among the reviewed studies, and the diameter of these canals at 
A

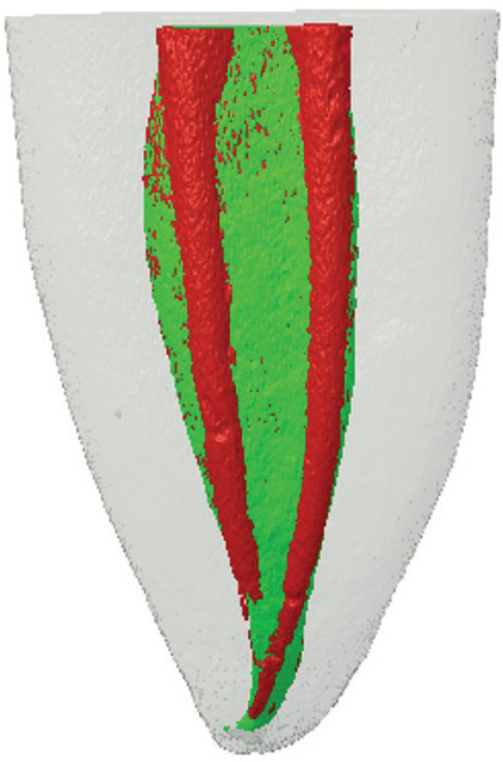

B

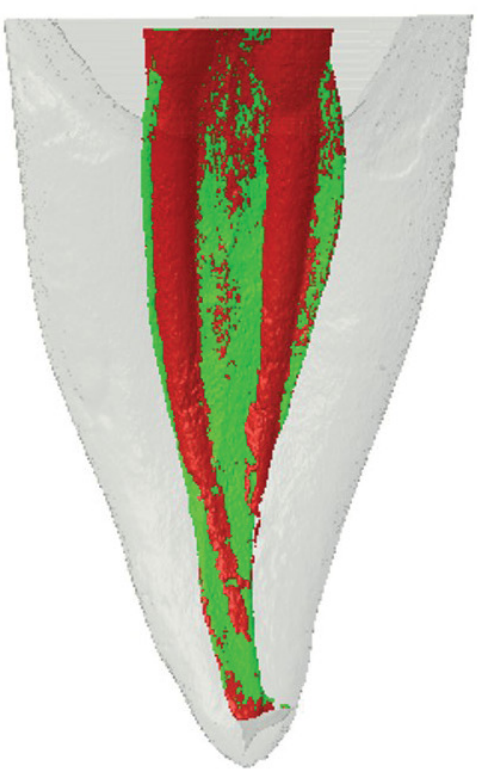

C
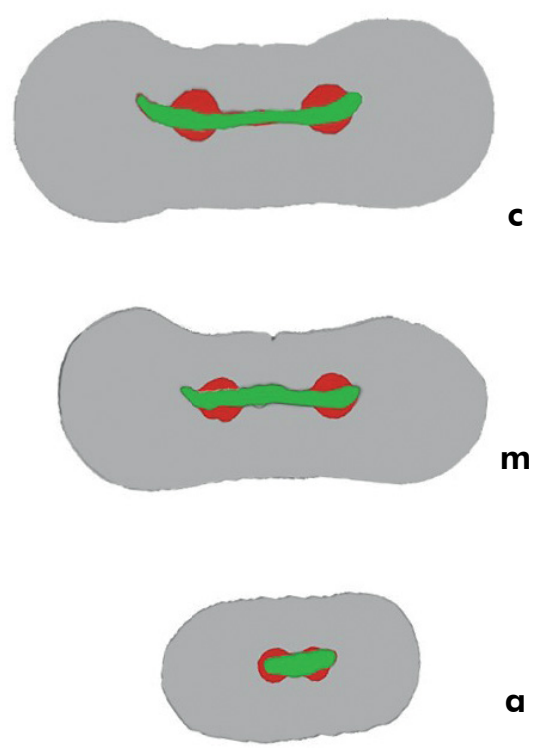

Figure 3. Representative 2D and 3D reconstructions of the internal and external anatomy of the mandibular molar before and after root canal preparation with mechanized instruments. (A) Buccal view of superimposed 3D models before (green) and after (red) root canal preparation. (B) Lingual view of superimposed 3D models before (green) and after (red) root canal preparation. (D) Representative cross-sections of the superimposed root canals before (green) and after (red) preparation at the cervical (c), middle $(\mathrm{m})$ and apical (a) thirds.

$1 \mathrm{~mm}$ of the apical foramen varied between $0.28-0.40$ $\mathrm{mm}$ in the buccolingual direction and $0.21-0.28 \mathrm{~mm}$ in the mesiodistal direction. ${ }^{134}$. The surgical diameter was similar to the anatomical diameter, which may also explain the large percentage of untouched walls. Therefore, the standardization of the anatomic diameter should be a concern for sample selection during the experimental design as this data can be determined by the parameters of major and minor diameter obtained by micro-CT as well as being clinically described by Pécora et al. ${ }^{135}$

In addition to the anatomical features of the dental group and instruments used for the preparation, another factor that can interfere in the results of touched walls is related to the evaluation methodology. The parameter of untouched walls is calculated by the difference between the number of static voxels and the total number of voxels on the surface of the root canal (voxels present at the same position on the canal surface before and after preparation). ${ }^{25}$ Both the overlap of the images and the resolution used for the acquisition of these images may be important factors in the interpretation of the obtained results ${ }^{31,84}$. The values of the resolutions used in the studies in this literature review ranged from $11.88 \mu \mathrm{m}$ to $36 \mu \mathrm{m},{ }^{25,42,79,88}$ with the best resolutions in Yang et al., ${ }^{88}$ with more values closer to $20 \mu \mathrm{m}$. Therefore, the observed differences in the percentage of untouched walls between studies may also be related to methodological differences.

It is known that bacteria may penetrate dentinal tubules in depths of $200 \mu \mathrm{m}$ or more, ${ }^{83,136}$ and the full extension and even the root canal by $200 \mu \mathrm{m}$ seems to be a goal not yet achieved by any preparation technique. ${ }^{24,7,7,11,12,13,1,4,1,25,27,28,29,30,31,34,35,37,38,39,40,41,42,43,44,45,47,57,58,59,}$ $62,63,68,79,80,81,82,83,84,85,86,87,88,89,90,91,92,93,94,95,96,97,98,99,100,101,102,103,104,105,106,107$

The untouched walls, especially in areas of anatomical challenges such as isthmus, recesses, and flattened root canals can retain bacteria and serve as a potential cause of persistent infection. ${ }^{137,138}$ This demonstrates the need for new strategies such as improving the performance of the irrigating solution, physical action of ultrasonic activation, and intracanal dressing to complement suboptimal mechanical action. ${ }^{30,61,79}$

Controversially, one study showed that there was no significant correlation between the elimination of active 
bacteria and the average percentage increase in volume, surface area, and untouched walls when analyzed by micro-CT. ${ }^{138}$ In addition, a recent study of the correlation between data obtained after biomechanical preparation using micro-CT and histology ${ }^{29}$ showed that even with the presence of untouched walls, SAF, TRUShape, and XP-endo Shaper can remove pulp tissue in oval canals. ${ }^{29}$

To analyze the changes in the dimensional shape of the root canal, the commonly used parameter is the SMI, which evaluates the convexity of the surface. Studies have shown that SMI values increased after preparation, indicating that the small and flatter irregularly tapered canal changed to a rounder and smoother tapered canal. $27,31,33,36,45,68,86,88,102,103$ Lower values for changes in SMI are related to the maintenance of the original shape of the root canal. .7,45,102 $^{2}$

Considering the limitations between the studies for analyzing the preparation related to changes in the geometry of the canals due to the methodological differences, the instruments showed that the most promising results regarding uniform dentin wear, smaller percentages of untouched walls, and the canal shape maintenance (evaluated by the SMI) especially on flattening canals, were the SAF, TRUShape, and XP-endo Shaper systems. ${ }^{4,29,30,31,33,63,85,102}$

\section{Expression of canal transportation and centering ability during the biomechanical preparation}

In 2017, the American Association of Endodontists ${ }^{139}$ defined the canal transportation as a removal of canal wall structure on the outside curve in the apical half of the canal due to the tendency of files to restore themselves to their original linear shape during canal preparations, which may lead to ledge formation and possible perforations. Gambill et al. ${ }^{140}$ proposed the term "centering ability" as a measurement of the ability of the instrument to stay centered in the canal. These measurements are still being used in various endodontic studies to assess the quality of the biomechanical preparation of root canals with instruments and techniques using different methodologies ${ }^{141}$. This was observed in this literature review in which $63.33 \%(n=38)$ of the studies evaluated the canal transportation and the centering ability.

Several factors can influence the canal transportation and centering ability such as errors in treating endodontic cavities and in glide path, use of non-flexible instruments, instrument design (cross-section, taper, tip) and the absence of specific treatments and alloys in endodontic instrument manufacturing (stainless steel, nickel-titanium, thermic treatment). In addition, negligence during irrigation protocols and the operator's experience in determining the most appropriate preparation technique for each situation should be considered. . $^{140,141,142}$ The importance of anatomical knowledge of the RCS and its variations such as radius and curvature degree, canal configuration, and dentin thickness which can be observed in two-dimensional radiographic examinations is noteworthy., $3140,141,142$

This literature review showed that approximately $52.63 \%(\mathrm{n}=20)$ of the studies reviewed evaluated the canal transportation and centering ability using the method proposed by Gambill et al. ${ }^{140}$ for a CBCT analysis. This methodology consists of the measurement of the shortest distance, in mesial and distal directions, from the limit of the noninstrumented root canal to the limit of the tooth in comparison with the same measurements of the instrumented areas, represented by the formula $\left(X^{1}-X^{2}\right)-\left(Y^{1}-Y^{2}\right)$. The $X^{1} / X^{2}$ and $Y^{1} / Y^{2}$ values represent the shortest distances from the outside and inside of the curved root to the periphery of the non-instrumented and instrumented areas of the root canals, respectively. Values may be seen from 0 (indicating no canal transportation) to 1 (indicating the perfect centering).

The high resolution and acuity of micro-CT allowed the evolution of this analysis, as introduced by Peters et al., ${ }^{131,143,144}$ comparing each slice voxel by voxel from all data sets obtained before and after root canal preparation to obtain consistent results for centers of gravity. In this case, each slice was defined by a series of coordinated data for the $\mathrm{x}-\mathrm{y}$-and z-axes, and the centers of gravity were calculated for each slice, connected along the $\mathrm{z}$-axis by a fitted line which can be analyzed to determine canal curvature as the second derivative. Thus, the comparison of the centers of gravity before and after preparation showed the results of canal transportation, ${ }^{45,97,131,143,144}$ as shown in $47.36 \%(n=18)$ of the studies in this review.

In general, besides the metallurgical properties and design of instruments, other factors including 
the procedural protocol and the anatomy of the RCSs can influence the canal transportation during instrumentation. This literature review showed that $86.84 \%(n=33)$ of the studies used mesial roots of mandibular molars with moderate curvature. In these studies, the results obtained showed that canal transportation at the apical region tended to occur in the lateral and outer surface of the canal curvature and in the inner surface of the canal curvature at the cervical and middle thirds. Regarding the thirds, all systems evaluated in this literature review showed root canal transportation mainly at the apical third in mesial root canals with moderate curvature. ${ }^{7,9,12,13,14,25,27,31,37,38,39,44,45,47,58,}$ $59,68,79,81,84,86,87,88,90,93,94,95,96,98,101,102,103,105,106$

Regarding kinematics of the instruments, it was possible to verify that the instruments that act in vibratory mode presented less variations of transport and centralization considering the entire root canal $(0.03 \mathrm{~mm}-0.14 \mathrm{~mm}){ }^{84}$ followed by the instruments in adaptive $(0.01 \mathrm{~mm}-0.058 \mathrm{~mm}),{ }^{47,58,}$, continuous $(0.00 \mathrm{~mm}-0.62 \mathrm{~mm}),{ }^{14,27}$ and reciprocating action (0.04 mm-0.48 mm). ${ }^{37,45}$ According to $\mathrm{Wu}$ et al., ${ }^{134}$ transportation in the apical third more than $0.3 \mathrm{~mm}$ could negatively affect the obturation sealing, ${ }^{38,86,134}$ and the values found in this review have not exceeded this critical limit in this root third.

Although the majority of the results did not present a statistical difference between the experimental groups in the performed studies, the reciprocating instruments were more likely to present values greater than 0.3 $\mathrm{mm}$. These higher values could be explained by the cross-sectional design of these instruments which, in the Reciproc instruments, has a sharp double-cutting edge and S-shaped geometry, while the WaveOne is characterized by a modified triangular cross section with radial lands at the tip and a convex triangular cross section in the middle and coronal portions of the instrument. These characteristics provide greater cutting power and consequently more canal transportation during root canal biomechanical preparation. ${ }^{37,86}$ Also, the reciprocating motion allows a balanced force for movement into the root canal. ${ }^{86,94,145}$

The necessity of carefully evaluating these parameters is evident because deviation from the original canal can lead to incomplete touch of the root canal walls, residual debris and necrotic tissues that can affect the root canal filling, or the formation of zips and perforations. Another problem is overpreparation, which can result in excessive dentin removal, root weakening, and fractures. ${ }^{97,131,140,141,142,144}$

\section{The influence of the kinematic and/ or motion type on the root canal biomechanical preparation}

Parallel to the advent of different materials and instruments from the use of stainless steel hand files to NiTi alloy mechanical systems, ${ }^{4,15,33,35,45,57,5,85,85,7,146}$ different kinematics were developed such as a continuous rotation, vibratory, reciprocating, and recently an adaptive motion, to prevent the screw effect. $6,15,33,43,62,85,86,105,146,147$ The use of systems in continuous kinematics has been widely studied, and $91.80 \%$ of the reviewed studies evaluated the effectiveness and the shaping ability of these instruments in the biomechanical preparation of the root canals, which may be related to the greater number of commercially available systems with the easy handling of continuous rotation.

In recent decades, rotary instruments have revolutionized endodontic science and are preferred by most clinicians and specialists because they provide higher quality and safer treatments. ${ }^{33,45,62,87,97,147}$ The constant evolution in the metallurgy and the design features of the NiTi alloy with its superelastic and shape memory properties improves the centering ability of the instruments through the root canal and decreases the canal transportation. ${ }^{82,133,146,147,148}$

Regarding root canal shaping, the NiTi rotary files using a continuous or adaptive motion have enhanced the quality of root canal preparation with less canal transportation, better centering ability, and minimal procedural errors such as zips and perforations, $15,21,83,85,86,91,149,150,151$ when compared with a reciprocating motion. ${ }^{15,35,45,91}$ Furthermore, reciprocating instruments allow more dentinal removal which may be caused by the different cross sections of these instruments. ${ }^{4,7,13,57,86,152}$

Another factor that may be related to the instrument kinematics is the amount of debris accumulation along the root canals and its extrusion, which may lead to postoperative pain and reinfection. $4,6,611,15,38,39,57,62,84,153,154$ Several studies have demonstrated that reciprocating motion is associated with more extrusion debris when 
compared with all of the other types of motion, since the material has no escape in the cervical direction, which favors the accumulation of debris in the apical and periapical regions. ${ }^{38,477,15,156}$

It is worth noting that despite the greater tendency to extrude debris, the reciprocating motion has been related to a greater reduction of bacteria, which may be associated with the modified convex triangular cross-section with radial lands at the tip and the convex triangular cross-section in the middle and coronal portion cross-sectional design, which allows greater cutting ability. $37,49,88,147,157,158,159$

\section{Conclusions}

The analysis of the biomechanical preparation studies evaluated with micro-CT show that anatomy, the design, and kinematics of the instruments, as well as the experimental design are factors that directly affect the quality of the biomechanical preparation of root canals. Despite the fact that the micro-CT presents high acuity, both for the study of the internal anatomy and for the biomechanical preparation, the difficulty in establishing criteria for selection and standardization of the sample in consideration of anatomical challenges is observed in the reviewed studies, which makes it challenging to determine the most effective instrumentation system (taper, kinematics, cross section and single or serial use) for each root canal morphology.

Also, the studies reviewed in the present analysis showed through micro-CT that none of the evaluated systems was able to completely touch the walls of the root canals. The effectiveness of the biomechanical preparation, as well as the maintenance of the channel shape, kinematics, and design of the instruments was evaluated. On the other hand, a greater trend of decentralization and transport of the root canals in the apical third was observed, as well as accumulation of debris after the use of reciprocating instruments.

In view of the results obtained in laboratory experiments by mean so micro-CT, theneed to transpose these data into clinical practice is clear. It is expected that in the future, the improvement and creation of new software for use in CBCT may allow the development of languages and logarithmic calculations in the correction of possible distortions generated during the scan, making possible the alignment and registration of images and subsequent clinical validation of the information obtained only by means of micro-CT thus far. With the development of these software programs, it will be possible to create tomographic models which will contribute to the planning of each clinical case. This new technology will determine more accurately the length of the canal, foraminal output, degree of curvature, major, and minor diameter of the canal, and the presence of isthmuses and accessory channels.

In addition, from the two-dimensional and threedimensional data of the root canal obtained by means of micro-CT and clinically by means of $\mathrm{CBCT}$, it will also be possible to develop applications capable of simulating the results of the isolated action of different instruments in the various alternatives in SCR, which may contribute to the planning of biomechanical preparation, as well as to the development of new instruments, increasing quality, and predictability during all stages of endodontic treatment.

\section{References}

1. Vertucci FJ. Root canal morphology and its relationship to endodontic procedures. 2005;10(1):3-29. https://doi.org/10.1111/j.1601-1546.2005.00129.x

2. Metzger Z, Teperovich E, Zary R, Cohen R, Hof R. The self-adjusting file (SAF). Part 1: respecting the root canal anatomy - a new concept of endodontic files and its implementation. J Endod. $2010 \mathrm{Apr} ; 36(4): 679-90$. https://doi.org/10.1016/i.joen.2009.12.036

3. Leoni GB, Versiani MA, Pécora JD, Sousa-Neto MD. Microcomputed tomographic analysis of the root canal morphology of mandibular incisors. J Endod. 2014 May;40(5):710-6.

https://doi.org/10.1016/i.joen.2013.09.003 P

4. Guimarães LS, Gomes CC, Marceliano-Alves MF,

Cunha RS, Provenzano JC, Siqueira JF Jr.

Preparation of oval-shaped canals with

TRUShape and reciproc systems: a micro-computed

tomography study using contralateral premolars.

J Endod. 2017 Jun;43(6):1018-22.

https://doi.org/10.1016/j.joen.2017.01.028 
5. Pereira RD, Brito-Júnior M, Leoni GB, Estrela C, SousaNeto MD. Evaluation of bond strength in single-cone fillings of canals with different cross-sections. Int Endod J. 2017 Feb;50(2):177-83. https://doi.org/10.1111/iej.12607

6. Bürklein S, Hinschitza K, Dammaschke T, Schäfer E. Shaping ability and cleaning effectiveness of two single-file systems in severely curved root canals of extracted teeth: Reciproc and WaveOne versus Mtwo and ProTaper. Int Endod J. 2012 May;45(5):449-61. https://doi.org/10.1111/j.1365-2591.2011.01996.x

7. Stern S, Patel S, Foschi F, Sherriff M, Mannocci F. Changes in centring and shaping ability using three nickel-titanium instrumentation techniques analysed by micro-computed tomography $(\mu \mathrm{CT})$. Int Endod J. 2012 Jun;45(6):514-23. https://doi.org/10.1111/i.1365-2591.2011.02004.x

8. Ruddle CJ, Machtou P, West JD. The shaping movement: fifth-generation technology. Dent Today. 2013 Apr;32(4):94,96-9.

9. Hwang YH, Bae KS, Baek SH, Kum KY, Lee W, Shon WJ, et al. Shaping ability of the conventional nickel-titanium and reciprocating nickel-titanium file systems: a comparative study using micro-computed tomography. J Endod. 2014 Aug;40(8):1186-9. https://doi.org/10.1016/i.joen.2013.12.032

10. Stavileci M, Hoxha V, Görduysus Ö, Tatar I, Laperre K, Hostens J et al. Evaluation of root canal preparation using rotary system and hand instruments assessed by micro-computed tomography. Med Sci Monit Basic Res. 2015;21:123-30. https://doi.org/10.12659/MSMBR.893950.

11. Coelho BS, Amaral RO, Leonardi DP, Marques-da-Silva B, Silva-Sousa YT, Carvalho FM et al. Performance of three single instrument systems in the preparation of long oval canals. Braz Dent J. 2016 Mar-Apr;27(2):217-22. https://doi.org/10.1590/0103-6440201302449

12. Yang Y, Shen Y, Ma J, Cao Y, Haapasalo M. A microcomputed tomographic assessment of the influence of operator's experience on the quality of waveone instrumentation. J Endod. 2016 Aug;42(8):1258-62. https://doi.org/10.1016/j.joen.2016.04.020

13. Jardine AP, Rosa RA, Santini MF, Zaccara IM, Só MV, Kopper $P M$. Shaping ability of rotatory or reciprocating instruments in curved canals: a micro-computed tomographic study. Braz Oral Res. 2016 Jun;30(1):S1806-83242016000100271. https://doi.org/10.1590/1807-3107BOR-2016.vol30.0086

14. Brasil SC, Marceliano-Alves MF, Marques ML, Grillo JP, Lacerda MF, Alves FR et al. Canal Transportation, Unprepared Areas, and Dentin Removal after Preparation with BT-RaCe and ProTaper Next Systems. J Endod. 2017 Oct;43(10):1683-7. https://doi.org/10.1016/j.joen.2017.04.012

15. Espir CG, Nascimento-Mendes CA, GuerreiroTanomaru JM, Freire LG, Gavini G, Tanomaru-Filho M. Counterclockwise or clockwise reciprocating motion for oval root canal preparation: a micro-CT analysis. Int Endod J. 2018 May;51(5):541-8. https://doi.org/10.1111/iej.12776

16. Wu MK, Wesselink PR. A primary observation on the preparation and obturation of oval canals. Int Endod J. 2001 Mar;34(2):137-41. Available from: https://www.ncbi.nlm.nih.gov/pubmed/11307262 https://doi.org/10.1046/j.1365-2591.2001.00361.x

17. Barbizam JV, Fariniuk LF, Marchesan MA, Pecora JD, SousaNeto MD. Effectiveness of manual and rotary instrumentation techniques for cleaning flattened root canals. J Endod. 2002 May;28(5):365-6. Available from: http://www.ncbi.nlm.nih. gov/pubmed/12026920https://doi.org/10.1097/00004770200205000-00004

18. Fariniuk LF, Baratto-Filho F, Cruz-Filho AM, Sousa-Neto MD. Histologic analysis of the cleaning capacity of mechanical endodontic instruments activated by the ENDOflash system. J Endod. 2003 Oct;29(10):651-3. Available from: http://www.ncbi.nlm.nih.gov/pubmed/14606788 https://doi.org/10.1097/00004770-200310000-00009

19. Ricucci $D$, Bergenholtz $G$. Bacterial status in root-filled teeth exposed to the oral environment by loss of restoration and fracture or caries: a histobacteriological study of treated cases. Int Endod J. 2003 Nov;36(11):787-802. Available from: http://www.ncbi.nlm.nih.gov/pubmed/14641443 https://doi.org/10.1046/j.1365-2591.2003.00721.x

20. Baratto-Filho F, Carvalho JR, Fariniuk LF, Sousa-Neto MD, Pécora JD, Cruz-Filho AM. Morphometric analysis of the effectiveness of different concentrations of sodium hypochlorite associated with rotary instrumentation for root canal cleaning. Braz Dent J. 2004;15(1):36-40. https://doi.org/S0103-64402004000100007.

21. Peters $O A$. Current challenges and concepts in the preparation of root canal systems: a review. J Endod. 2004 Aug;30(8):559-67. Available from: http://www.ncbi.nlm. nih.gov/pubmed/15273636https://doi.org/10.1097/01. DON.0000129039.59003.9D

22. Paqué F, Ganahl D, Peters OA. Effects of root canal preparation on apical geometry assessed by microcomputed tomography. J Endod. 2009 Jul;35(7):1056-9. https://doi.org/10.1016/i.joen.2009.04.020

23. Metzger Z, Teperovich E, Cohen R, Zary R, Paqué $F$, Hülsmann M. The self-adjusting file (SAF). Part 3: removal of debris and smear layer-A scanning electron microscope study. J Endod. 2010 Apr;36(4):697-702. https://doi.org/10.1016/i.joen.2009.12.037

24. Hübscher W, Barbakow F, Peters OA. Root canal preparation with FlexMaster: assessment of torque and force in relation to canal anatomy. Int Endod J. 2003 Dec;36(12):883-90.

25. Peters $\mathrm{OA}$, Peters $\mathrm{Cl}$, Schönenberger K, Barbakow F. ProTaper rotary root canal preparation: effects of canal anatomy on final shape analysed by micro CT. Int Endod J. 2003 Feb;36(2):86-92. https://doi.org/10.1046/j.1365-2591.2003.00626.x 
26. Yared G. Canal preparation using only one $\mathrm{Ni}$ Ti rotary instrument: preliminary observations. Int Endod J. 2008 Apr;41(4):339-44. https://doi.org/10.1111/j.1365-2591.2007.01351.x

27. Gagliardi J, Versiani MA, de Sousa-Neto MD, Plazas-Garzon A, Basrani B. Evaluation of the shaping characteristics of ProTaper Gold, ProTaper NEXT, and ProTaper Universal in curved canals. J Endod. 2015 Oct;41(10):1718-24. https://doi.org/10.1016/i.joen.2015.07.009

28. De-Deus G, Silva EJ, Vieira VT, Belladonna FG, Elias $C N$, Plotino $G$ et al. Blue thermomechanical treatment optimizes fatigue resistance and flexibility of the reciproc files. J Endod. 2017 Mar;43(3):462-6. https://doi.org/10.1016/i.joen.2016.10.039

29. Lacerda MF, Marceliano-Alves MF, Pérez AR, Provenzano JC, Neves MA, Pires FR et al. Cleaning and shaping oval canals with 3 instrumentation systems: a correlative micro-computed tomographic and histologic study. J Endod. 2017 Nov;43(11):1878-84. https://doi.org/10.1016/i.joen.2017.06.032

30. Zuolo ML, Zaia AA, Belladonna FG, Silva EJ, Souza EM, Versiani MA et al. Micro-CT assessment of the shaping ability of four root canal instrumentation systems in oval-shaped canals. Int Endod J. 2018;51(5):564-71. https://doi.org/10.1111/iej.12810

31. Paqué F, Peters OA. Micro-computed tomography evaluation of the preparation of long oval root canals in mandibular molars with the selfadjusting file. J Endod. 2011 Apr;37(4):517-21. https://doi.org/10.1016/j.joen.2010.12.011

32. Versiani MA, Pécora JD, Sousa-Neto MD. The anatomy of two-rooted mandibular canines determined using microcomputed tomography. Int Endod J. 2011 Jul;44(7):682-7. https://doi.org/10.1111/j.1365-2591.2011.01879.x

33. Versiani MA, Pécora JD, Sousa-Neto MD. Microcomputed tomography analysis of the root canal morphology of single-rooted mandibular canines. Int Endod J. 2013 Sep;46(9):800-7. https://doi.org/10.1111/iej.12061

34. Ahmetoglu F, Keles A, Simsek N, Ocak MS, Yologlu S. Comparative evaluation of root canal preparations of maxillary first molars with self-adjusting file, reciproc single file, and revo-s rotary file: A micro-computed tomography study. Scanning. 2015 May-Jun;37(3):218-25. https://doi.org/10.1002/sca.21202

35. Keleş A, Alçin H, Sousa-Neto MD, Versiani MA. Supplementary Steps for Removing Hard Tissue Debris from Isthmus-containing Canal Systems. J Endod. 2016 Nov;42(11):1677-82. https://doi.org/10.1016/i.joen.2016.07.025

36. Kim Y, Chang SW, Lee JK, Chen IP, Kaufman B, Jiang $J$, et al. A micro-computed tomography study of canal configuration of multiple-canalled mesiobuccal root of maxillary first molar. Clin Oral Investig. 2013 Jul;17(6):1541-6. https://doi.org/10.1007/s00784-012-0852-8
37. Gergi R, Arbab-Chirani R, Osta N, Naaman A. Microcomputed tomographic evaluation of canal transportation instrumented by different kinematics rotary nickeltitanium instruments. J Endod. 2014 Aug;40(8):1223-7. https://doi.org/10.1016/i.joen.2014.01.039

38. Junaid A, Freire LG, Bueno CES, Mello I, Cunha RS. Influence of single-file endodontics on apical transportation in curved root canals: an ex vivo micro-computed tomographic study. J Endod. 2014 May;40(5):717-20. https://doi.org/10.1016/i.joen.2013.09.021

39. McRay B, Cox TC, Cohenca N, Johnson JD, Paranipe A. A micro-computed tomography-based comparison of the canal transportation and centering ability of ProTaper Universal rotary and WaveOne reciprocating files. Quintessence Int. 2014 Feb;45(2):101-8. https://doi.org/10.3290/i.qi.a30998

40. Sant'Anna Júnior $A$, Cavenago BC, OrdinolaZapata R, De-Deus G, Bramante CM, Duarte MA. The effect of larger apical preparations in the danger zone of lower molars prepared using the Mtwo and Reciproc systems. J Endod. 2014 Nov;40(11):1855-9. https://doi.org/10.1016/i.joen.2014.06.020

41. Zhao D, Shen Y, Peng B, Haapasalo M. Root canal preparation of mandibular molars with 3 nickel-titanium rotary instruments: a micro-computed tomographic study. J Endod. 2014 Nov;40(11):1860-4. https://doi.org/10.1016/i.joen.2014.06.023

42. Busquim S, Cunha RS, Freire L, Gavini G, Machado ME, Santos M. A micro-computed tomography evaluation of long-oval canal preparation using reciprocating or rotary systems. Int Endod J. 2015 Oct;48(10):1001-6. https://doi.org/10.1111/iej.12398

43. De-Deus G, Belladonna FG, Silva EJ, Marins JR, Souza EM, Perez R et al. Micro-CT Evaluation of Non-instrumented Canal Areas with Different Enlargements Performed by NiTi Systems. Braz Dent J. 2015 Nov-Dec;26(6):624-9. https://doi.org/10.1590/0103-6440201300116

44. Gergi R, Osta N, Bourbouze G, Zgheib C, Arbab-Chirani $R$, Naaman A. Effects of three nickel titanium instrument systems on root canal geometry assessed by microcomputed tomography. Int Endod J. 2015 Feb;48(2):162-70. https://doi.org/10.1111/iej.12296

45. Marceliano-Alves MF, Sousa-Neto MD, Fidel SR, Steier L, Robinson JP, Pécora JD et al. Shaping ability of single-file reciprocating and heat-treated multifile rotary systems: a micro-CT study. Int Endod J. 2015 Dec;48(12):1129-36. https://doi.org/10.1111/iej.12412

46. Lopes HP, Elias CN, Vieira MV, Siqueira JF Jr, Mangelli M, Lopes WS et al. Fatigue life of reciproc and Mtwo instruments subjected to static and dynamic tests. J Endod. 2013 May;39(5):693-6. https://doi.org/10.1016/i.joen.2012.11.048

47. Pedullà E, Plotino 2, Grande N3, Avarotti 4, Gambarini 5 , Rapisarda 4 et al. Shaping ability of two nickeltitanium instruments activated by continuous rotation or adaptive motion: a micro-computed tomography study. Clin Oral Investig. 2016;20(8):2227-33. https://doi.org/10.1007/s00784-016-1732-4 
48. Varela-Patiño P, Ibañez-Párraga $A$, Rivas-Mundiña $B$, Cantatore G, Otero XL, Martin-Biedma B. Alternating versus continuous rotation: a comparative study of the effect on instrument life. J Endod. 2010 Jan;36(1):157-9. https://doi.org/10.1016/i.joen.2009.09.023

49. Dhingra A, Ruhal N, Miglani A. Evaluation of single file systems reciproc, oneshape, and waveone using cone beam computed tomography -an in vitro study. J Clin Diagn Res. 2015 Apr;9(4):ZC30-4. https://doi.org/10.7860/JCDR/2015/12112.5803

50. Elsaka SE, Elnaghy AM. Cyclic fatigue resistance of OneShape and WaveOne instruments using different angles of curvature. Dent Mater J. 2015;34(3):358-63. https://doi.org/10.4012/dmi.2014-252

51. Bürklein S, Benten S, Schäfer E. Shaping ability of different single-file systems in severely curved root canals of extracted teeth. Int Endod J. 2013 Jun;46(6):590-7. https://doi.org/10.1111/iej.12037

52. Saber SE, Nagy MM, Schäfer E. Comparative evaluation of the shaping ability of WaveOne, Reciproc and OneShape single-file systems in severely curved root canals of extracted teeth. Int Endod J. 2015 Jan;48(1):109-14. https://doi.org/10.1111/iej.12289

53. Gambarini G, Gergi R, Naaman A, Osta N, Al Sudani D. Cyclic fatigue analysis of twisted file rotary $\mathrm{NiTi}$ instruments used in reciprocating motion. Int Endod J. 2012 Sep;45(9):802-6. https://doi.org/10.1111/i.1365-2591.2012.02036.x

54. Gambarini G, Gergi R, Grande NM, Osta N, Plotino G, Testarelli L. Cyclic fatigue resistance of newly manufactured rotary nickel titanium instruments used in different rotational directions. Aust Endod J. 2013 Dec;39(3):151-4. https://doi.org/10.1111/j.1747-4477.2012.00353.x

55. Capar ID, Arslan H, Ertas H, Gök T, Saygılı G. Effectiveness of ProTaper Universal retreatment instruments used with rotary or reciprocating adaptive motion in the removal of root canal filling material. Int Endod J. 2015 Jan;48(1):79-83. https://doi.org/10.1111/iej.12279

56. Crozeta BM, Silva-Sousa YT, Leoni GB, Mazzi-Chaves $J F$, Fantinato T, Baratto-Filho F et al. Micro-computed tomography study of filling material removal from oval-shaped canals by using rotary, reciprocating, and adaptive motion systems. J Endod. 2016 May;42(5):793-7. https://doi.org/10.1016/j.joen.2016.02.005

57. Lopes RM, Marins FC, Belladonna FG, Souza EM, DeDeus $G$, Lopes RT et al. Untouched canal areas and debris accumulation after root canal preparation with rotary and adaptive systems. Aust Endod J. 2017 Sep 20. https://doi.org/10.1111/aej.12237

58. Silva EJ, Pacheco PT, Pires F, Belladonna FG, De-Deus $G$. Microcomputed tomographic evaluation of canal transportation and centring ability of ProTaper Next and Twisted File Adaptive systems. Int Endod J. 2017 Jul;50(7):694-9. https://doi.org/10.1111/iej.12667
59. Elnaghy AM, Al-Dharrab AA, Abbas HM, Elsaka SE. Evaluation of root canal transportation, centering ratio, and remaining dentin thickness of TRUShape and ProTaper Next systems in curved root canals using micro-computed tomography. Quintessence Int. 2017;48(1):27-32. https://doi.org/10.3290/i.qi.a36895

60. Bao P, Shen Y, Lin J, Haapasalo M. In vitro efficacy of XPendo finisher with 2 different protocols on biofilm removal from apical root canals. J Endod. 2017 Feb;43(2):321-5. https://doi.org/10.1016/i.joen.2016.09.021

61. Leoni GB, Versiani MA, Silva-Sousa YT, Bruniera JF, Pécora JD, Sousa-Neto MD. Ex vivo evaluation of four final irrigation protocols on the removal of hard-tissue debris from the mesial root canal system of mandibular first molars. Int Endod J. 2017 Apr;50(4):398-406. https://doi.org/10.1111/iej.12630

62. Azim AA, Piasecki L, Silva Neto UX, Cruz AT, Azim KA. XP shaper, a novel adaptive core rotary instrument: micro-computed tomographic analysis of its shaping abilities. J Endod. 2017 Sep;43(9):1532-8. https://doi.org/10.1016/i.joen.2017.04.022PMID:28735789

63. Versiani MA, Carvalho KK, Mazzi-Chaves JF, Sousa-Neto MD. Micro-computed tomographic evaluation of the shaping ability of XP-endo shaper, $\mathrm{iRaCe}$, and EdgeFile systems in long oval-shaped canals. J Endod. 2018;44(3):489-95. https://doi.org/10.1016/i.joen.2017.09.008

64. Gutmann JL, Gao Y. Alteration in the inherent metallic and surface properties of nickel-titanium root canal instruments to enhance performance, durability and safety: a focused review. Int Endod J. 2012 Feb;45(2):113-28. https://doi.org/10.1111/j.1365-2591.2011.01957.x

65. Bayram HM, Bayram E, Ocak M, Uzuner MB, Geneci F, Celik HH. Micro-computed tomographic evaluation of dentinal microcrack formation after using new heat-treated nickel-titanium systems. J Endod. 2017 Oct;43(10):1736-9. https://doi.org/ 10.1016/j.joen.2017.05.024

66. Topçuoğlu HS, Topçuoğlu G. Cyclic fatigue resistance of reciproc blue and reciproc files in an s-shaped canal. J Endod. 2017 Oct;43(10):1679-82. https://doi.org/10.1016/i.joen.2017.04.009

67. Fan B, Yang J, Gutmann JL, Fan M. Root canal systems in mandibular first premolars with $\mathrm{C}$-shaped root configurations. Part I: microcomputed tomography mapping of the radicular groove and associated root canal cross-sections. J Endod. 2008 Nov;34(11):1337-41. https://doi.org/10.1016/i.joen.2008.08.006 PMID:18928842

68. Gekelman D, Ramamurthy R, Mirfarsi S, Paqué F, Peters OA. Rotary nickel-titanium GT and ProTaper files for root canal shaping by novice operators: a radiographic and micro-computed tomography evaluation. J Endod. 2009 Nov;35(11):1584-8. https://doi.org/10.1016/i.joen.2009.07.018

69. Alencar AH, Dummer PM, Oliveira HC, Pécora JD, Estrela C. Procedural errors during root canal preparation using rotary $\mathrm{NiTi}$ instruments detected by periapical radiography and cone 
beam computed tomography. Braz Dent J. 2010;21(6):543-9. https://doi.org/10.1590/S0103-64402010000600011

70. Kunert GG, Camargo Fontanella VR, Moura AA, Barletta FB. Analysis of apical root transportation associated with ProTaper Universal F3 and F4 instruments by using digital subtraction radiography. J Endod. 2010 Jun;36(6):1052-5. https://doi.org/10.1016/j.joen.2010.02.004

71. Bramante CM, Berbert A, Borges RP. A methodology for evaluation of root canal instrumentation. J Endod. 1987 May;13(5):243-5. https://doi.org/10.1016/S0099-2399(87)80099-7

72. Hulsmann M, Peters OA, Dummer PM. Mechanical preparation of root canals: shaping goals, techniques and means. Endod Topics. 2005;10(1):30-76. https://doi.org/10.1111/j.1601-1546.2005.00152.x

73. Dowker SE, Davis GR, Elliott JC. X-ray microtomography: nondestructive three-dimensional imaging for in vitro endodontic studies. Oral Surg Oral Med Oral Pathol Oral Radiol Endod. 1997 Apr;83(4):510-6. https://doi.org/10.1016/S1079-2104(97)90155-4

74. Paqué F, Barbakow F, Peters OA. Root canal preparation with Endo-Eze AET: changes in root canal shape assessed by micro-computed tomography. Int Endod J. 2005 Jul;38(7):456-64. https://doi.org/10.1111/j.1365-2591.2005.00968.x

75. Taşdemir T, Er K, Yildirim T, Buruk K, Celik D, Cora S et al. Comparison of the sealing ability of three filling techniques in canals shaped with two different rotary systems: a bacterial leakage study. Oral Surg Oral Med Oral Pathol Oral Radiol Endod. 2009 Sep;108(3):e129-34. https://doi.org/10.1016/j. tripleo.2009.05.007 PMID:19716483

76. Tachibana H, Matsumoto K. Applicability of X-ray computerized tomography in endodontics. Endod Dent Traumatol. 1990 Feb;6(1):16-20.

77. Baumann MA, Doll GM. Spatial reproduction of the root canal system by magnetic resonance microscopy. J Endod. 1997 Jan;23(1):49-51. https://doi.org/10.1016/S0099-2399(97)80207-5

78. Sá Neto JL, Simão MN, Crema MD, Engel EE, NogueiraBarbosa MH. Diagnostic performance of magnetic resonance imaging in the assessment of periosteal reactions in bone sarcomas using conventional radiography as the reference. Radiol Bras. 2017 May-Jun;50(3):176-81. https://doi.org/10.1590/0100-3984.2015.0166

79. Hübscher W, Barbakow F, Peters OA. Root-canal preparation with FlexMaster: canal shapes analysed by micro-computed tomography. Int Endod J. 2003 Nov;36(11):740-7. https://doi.org/10.1046/i.1365-2591.2003.00723.x

80. Peru M, Peru C, Mannocci F, Sherriff M, Buchanan LS, Pitt Ford TR. Hand and nickel-titanium root canal instrumentation performed by dental students: a micro-computed tomographic study. Eur J Dent Educ. 2006 Feb;10(1):52-9. https://doi.org/10.1111/j.1600-0579.2006.00395.x
81. Loizides AL, Kakavetsos VD, Tzanetakis GN, Kontakiotis $E G$, Eliades $G$. A comparative study of the effects of two nickel-titanium preparation techniques on root canal geometry assessed by microcomputed tomography. J Endod. 2007 Dec;33(12):1455-9. https://doi.org/10.1016/i.joen.2007.07.019

82. Cheung LH, Cheung GS. Evaluation of a rotary instrumentation method for $\mathrm{C}$-shaped canals with microcomputed tomography. J Endod. 2008 Oct;34(10):1233-8. https://doi.org/10.1016/i.joen.2008.07.015

83. Peters $O A$, Boessler $C$, Paqué F. Root canal preparation with a novel nickel-titanium instrument evaluated with micro-computed tomography: canal surface preparation over time. J Endod. 2010 Jun;36(6):1068-72. https://doi.org/10.1016/i.joen.2010.02.023

84. Peters $O A$, Paqué $F$. Root canal preparation of maxillary molars with the self-adjusting file: a micro-computed tomography study. J Endod. 2011 Jan;37(1):53-7. https://doi.org/10.1016/i.joen.2010.08.047

85. Versiani MA, Pécora JD, de Sousa-Neto MD. Flat-oval root canal preparation with self-adjusting file instrument: a microcomputed tomography study. J Endod. 2011 Jul;37(7):10027. https://doi.org/10.1016/i.joen.2011.03.017

86. You SY, Kim HC, Bae KS, Baek SH, Kum KY, Lee W. Shaping ability of reciprocating motion in curved root canals: a comparative study with micro-computed tomography. J Endod. 2011 Sep;37(9):1296-300. https://doi.org/10.1016/i.joen.2011.05.021

87. Paqué F, Zehnder M, De-Deus G. Microtomography-based comparison of reciprocating single-file F2 ProTaper technique versus rotary full sequence. J Endod. 2011 Oct;37(10):13947. https://doi.org/10.1016/i.joen.2011.06.031

88. Yang G, Yuan G, Yun X, Zhou X, Liu B, Wu H. Effects of two nickel-titanium instrument systems, Mtwo versus ProTaper universal, on root canal geometry assessed by microcomputed tomography. J Endod. 2011 Oct;37(10):1412-6. https://doi.org/10.1016/i.joen.2011.06.024

89. Freire LG, Gavini G, Branco-Barletta F, Sanches-Cunha R, Santos M. Microscopic computerized tomographic evaluation of root canal transportation prepared with twisted or ground nickel-titanium rotary instruments. Oral Surg Oral Med Oral Pathol Oral Radiol Endod. 2011 Dec;112(6):e143-8. https://doi.org/10.1016/j.tripleo.2011.06.029

90. Yamamura B, Cox TC, Heddaya B, Flake NM, Johnson JD, Paranipe A. Comparing canal transportation and centering ability of endosequence and vortex rotary files by using micro-computed tomography. J Endod. 2012 Aug;38(8):1121-5. https://doi.org/10.1016/i.joen.2012.04.019

91. Versiani MA, Leoni GB, Steier L, De-Deus G, Tassani S, Pécora JD et al. Micro-computed tomography study of ovalshaped canals prepared with the self-adjusting file, Reciproc, WaveOne, and ProTaper universal systems. J Endod. 2013 Aug;39(8):1060-6. https://doi.org/10.1016/i.joen.2013.04.009 
92. Kim HC, Hwang YJ, Jung DW, You SY, Kim HC, Lee W. Micro-computed tomography and scanning electron microscopy comparisons of two nickel-titanium rotary root canal instruments used with reciprocating motion. Scanning. 2013 Mar-Apr;35(2):112-8. https://doi.org/10.1002/sca.21039

93. Zhao D, Shen Y, Peng B, Haapasalo M. Micro-computed tomography evaluation of the preparation of mesiobuccal root canals in maxillary first molars with Hyflex CM, Twisted Files, and K3 instruments. J Endod. 2013 Mar;39(3):385-8. https://doi.org/10.1016/i.joen.2012.11.030

94. Ceyhanli KT, Erdilek N, Tatar I, Cetintav B. Comparative micro-computed tomography evaluation of apical root canal transportation with the use of ProTaper, RaCe and Safesider systems in human teeth. Aust Endod J. 2014 Apr;40(1):12-6. https://doi.org/10.1111/aej.12014

95. Al-Sudani D, Almalki M, Al-Shahrani S, Ahlquist M. Geometric analysis of maxillary first premolar prepared by two nickel-titanium rotary instruments. J Contemp Dent Pract. 2014 Mar;15(2):174-80.

96. Almeida BC, Ormiga F, Araújo MC, Lopes RT, Lima IC, Santos BC et al. Influence of heat treatment of nickel-titanium rotary endodontic instruments on apical preparation: a micro-computed tomographic study. J Endod. 2015 Dec;41(12):2031-5. https://doi.org/10.1016/j.joen.2015.09.001

97. Peters OA, Arias A, Paqué F. A Micro-computed tomographic assessment of root canal preparation with a novel instrument, TRUShape, in mesial roots of mandibular molars. J Endod. 2015 Sep;41(9):1545-50. https://doi.org/10.1016/i.joen.2015.06.007

98. Pasqualini D, Alovisi M, Cemenasco A, Mancini L, Paolino DS, Bianchi CC et al. Micro-computed tomography evaluation of protaper next and biorace shaping outcomes in maxillary first molar curved canals. J Endod. 2015 Oct;41(10):1706-10. https://doi.org/10.1016/i.joen.2015.07.002

99. Santa-Rosa J, Sousa-Neto MD, Versiani MA, Nevares $G$, Xavier F, Romeiro K et al. Shaping ability of singlefile systems with different movements: a micro-computed tomographic study. Iran Endod J. 2016;11(3):228-33. https://doi.org/10.7508/iej.2016.03.016

100. Vallaeys K, Chevalier V, Arbab-Chirani R. Comparative analysis of canal transportation and centring ability of three $\mathrm{Ni}$-Ti rotary endodontic systems: Protaper ${ }^{\circledR}$, MTwo ${ }^{\circledR}$ and Revo-S ${ }^{\mathrm{TM}}$, assessed by micro-computed tomography. Odontology. 2016 Jan;104(1):83-8. https://doi.org/10.1007/s10266-014-0176-z

101. da Silva Limoeiro AG, Dos Santos AH, De Martin AS, Kato AS, Fontana CE, Gavini G et al. Micro-computed tomographic evaluation of 2 nickel-titanium instrument systems in shaping root canals. J Endod. 2016 Mar;42(3):496-9. https://doi.org/10.1016/i.joen.2015.12.007
102. Arias A. Paqu? F, Shyn S, Murphy S, Peters OA. Effect of canal preparation with TRUShape and Vortex rotary instruments on three-dimensional geometry of oval root canals. Aust Endod J. 2018;44(1):32-9. https://doi.org/10.1111/aej.12201

103. Venino PM, Citterio CL, Pellegatta A, Ciccarelli $M$, Maddalone M. A Micro-computed tomography evaluation of the shaping ability of two nickel-titanium instruments, HyFlex EDM and ProTaper Next. J Endod. 2017 Apr;43(4):628-32. https://doi.org/10.1016/i.joen.2016.11.022

104. Duque JA, Vivan RR, Cavenago BC, Amoroso-Silva PA, Bernardes RA, Vasconcelos BC et al. Influence of $\mathrm{NiTi}$ alloy on the root canal shaping capabilities of the ProTaper Universal and ProTaper Gold rotary instrument systems. J Appl Oral Sci. 2017 Jan-Feb;25(1):27-33. https://doi.org/10.1590/1678-77572016-0230

105. Serefoglu B, Piskin B. Micro computed tomography evaluation of the Self-adjusting file and ProTaper Universal system on curved mandibular molars. Dent Mater J. 2017 Sep;36(5):606-13. https://doi.org/10.4012/dmi.2016-255

106. Freire LG, Gavini G, Cunha RS, Santos M. Assessing apical transportation in curved canals: comparison between cross-sections and micro-computed tomography. Braz Oral Res. 2012;26(3):222-7. https://doi.org/10.1590/S1806-83242012000300007

107. Moura-Netto C, Palo RM, Camargo CH, Pameijer CH, Bardauil MR. Micro-CT assessment of two different endodontic preparation systems. Braz Oral Res. 2013;27(1):26-30.

108. Souza-Flamini LE, Leoni GB, Chaves JF, Versiani MA, Cruz-Filho AM, Pécora JD et al. The radix entomolaris and paramolaris: a micro-computed tomographic study of 3-rooted mandibular first molars. J Endod. 2014 Oct;40(10):1616-21. https://doi.org/10.1016/i.joen.2014.03.012

109. Brito-Júnior M, Leoni GB, Pereira RD, et al. A novel dentin push-out bond strength model that uses microcomputed tomography. J Endod. 2015;41(12):2058-2063. https://doi.org/10.1016/i.joen.2015.09.009

110. Liberati A, Altman DG, Tetzlaff J, Mulrow C, Gøtzsche PC, loannidis JP et al. The PRISMA statement for reporting systematic reviews and meta-analyses of studies that evaluate health care interventions: explanation and elaboration. PLoS Med. 2009 Jul;6(7):e1000100. https://doi.org/10.1371/journal.pmed.1000100

111. Pautasso M. Ten simple rules for writing a literature review. PLoS Comput Biol. 2013. https://doi.org/10.1371/journal.pcbi.1003149

112. Preiswerk G. Die pulpaamputation, eine klinische, pathohistologische and bakteriologische studie. D Cosm. 1901;67(1):581-92.

113. Prinz H. The Spalteholz method of preparing trasparent animal bodies. D Cosm Cosm. 1913;55(1):374-8.

114. Okumura T. Anatomy of the root canals. J Am Dent Assoc. 1927;14(4):632-40. 
Root canal preparation using micro-computed tomography analysis: a literature review

115. Vertucci FJ. Root canal anatomy of the human permanent teeth. Oral Surg Oral Med Oral Pathol. 1984 Nov;58(5):589-99.

116. Kartal N, Yanikoğlu FC. Root canal morphology of mandibular incisors. J Endod. $1992 \mathrm{Nov} ; 18(11): 562-4$. https://doi.org/10.1016/S0099-2399(06)81215-X

117. Sert S, Aslanalp V, Tanalp J. Investigation of the root canal configurations of mandibular permanent teeth in the Turkish population. Int Endod J. 2004 Jul;37(7):494-9. https://doi.org/10.1111/j.1365-2591.2004.00837.x

118. Gulabivala K, Aung TH, Alavi A, Ng YL. Root and canal morphology of Burmese mandibular molars. Int Endod J. 2001 Jul;34(5):359-70.

119. Ng YL, Aung TH, Alavi A, Gulabivala K. Root and canal morphology of Burmese maxillary molars. Int Endod J. 2001 Dec;34(8):620-30. https://doi.org/10.1046/i.1365-2591.2001.00438.x

120. Gulabivala K, Opasanon A, Ng YL, Alavi A. Root and canal morphology of Thai mandibular molars. Int Endod J. 2002 Jan;35(1):56-62. https://doi.org/10.1046/j.1365-2591.2002.00452.x

121. Al-Qudah AA, Awawdeh LA. Root canal morphology of mandibular incisors in a Jordanian population. Int Endod J. 2006 Nov;39(11):873-7. https://doi.org/10.1111/j.1365-2591.2006.01159.x

122. Villas-Bôas MH, Bernardineli N, Cavenago BC, Marciano M, Del Carpio-Perochena A, Moraes IG et al. Micro-computed tomography study of the internal anatomy of mesial root canals of mandibular molars. J Endod. 2011;37(12):1682-6. https://doi.org/10.1016/i.joen.2011.08.001

123. Boschetti E, Silva-Sousa YT, Mazzi-Chaves JF, Leoni GB, Versiani MA, Pécora JD et al. Micro-CT Evaluation of Root and Canal Morphology of Mandibular First Premolars with Radicular Grooves. Braz Dent J. 2017 Sep-Oct;28(5):597-603. https://doi.org/10.1590/0103-6440201601784

124. Versiani MA, Sousa-Neto MD, Pécora JD. Pulp pathosis in inlayed teeth of the ancient Mayas: a microcomputed tomography study. Int Endod J. 2011 Nov;44(11):1000-4. https://doi.org/10.1111/j.1365-2591.2011.01905.x

125. Versiani MA, Pécora JD, Sousa-Neto MD. Root and root canal morphology of four-rooted maxillary second molars: a microcomputed tomography study. J Endod. 2012 Jul;38(7):977-82. https://doi.org/10.1016/i.joen.2012.03.026

126. Nunes CA, Guedes OA, Alencar AH, Peters OA, Estrela $C R$, Estrela C. Evaluation of Periapical Lesions and Their Association with Maxillary Sinus Abnormalities on Conebeam Computed Tomographic Images. J Endod. 2016 Jan;42(1):42-6. https://doi.org/10.1016/i.joen.2015.09.014

127. Ordinola-Zapata R, Monteiro Bramante C, Gagliardi Minotti P, Cavalini Cavenago B, Gutmann JL, Moldaver $\mathrm{Bl}$ et al. Micro-CT evaluation of C-shaped mandibular first premolars in a Brazilian subpopulation. Int Endod J. 2015 Aug;48(8):807-13. https://doi.org/10.1111/iej.12380
128. Fan B, Pan Y, Gao Y, Fang F, Wu Q, Gutmann JL. Threedimensional morphologic analysis of isthmuses in the mesial roots of mandibular molars. J Endod. 2010 Nov;36(11):18669. https://doi.org/10.1016/i.joen.2010.08.030

129. De-Deus $G$. Research that matters - root canal filling and leakage studies. Int Endod J. 2012 Dec;45(12):1063-4. https://doi.org/10.1111/j.1365-2591.2012.02104.x

130. Rhodes JS, Ford TR, Lynch JA, Liepins PJ, Curtis RV. A comparison of two nickel-titanium instrumentation techniques in teeth using microcomputed tomography. Int Endod J. 2000 May;33(3):279-85. https://doi.org/10.1046/j.1365-2591.1999.00306.x

131. Peters OA, Schönenberger K, Laib A. Effects of four $\mathrm{Ni}$-Ti preparation techniques on root canal geometry assessed by micro computed tomography. Int Endod J. 2001 Apr;34(3):221-30. https://doi.org/10.1046/j.1365-2591.2001.00373.x

132. Peters OA, Laib A, Göhring TN, Barbakow F. Changes in root canal geometry after preparation assessed by high-resolution computed tomography. J Endod. 2001 Jan;27(1):1-6. https://doi.org/10.1097/00004770-200101000-00001

133. Bergmans L, Van Cleynenbreugel J, Wevers $M$, Lambrechts P. A methodology for quantitative evaluation of root canal instrumentation using microcomputed tomography. Int Endod J. 2001 Jul;34(5):390-8. https://doi.org/10.1046/j.1365-2591.2001.00413.x

134. Wu MK, R'oris A, Barkis D, Wesselink PR. Prevalence and extent of long oval canals in the apical third. Oral Surg Oral Med Oral Pathol Oral Radiol Endod. 2000 Jun;89(6):73943. https://doi.org/10.1067/moe.2000.106344

135. Pecora JD, Capelli A, Guerisoli DM, Spanó JC, Estrela C. Influence of cervical preflaring on apical file size determination. Int Endod J. 2005 Jul;38(7):430-5. https://doi.org/10.1111/j.1365-2591.2005.00946.x

136. Love RM, Jenkinson HF. Invasion of dentinal tubules by oral bacteria. Crit Rev Oral Biol Med. 2002;13(2):171-83.

137. Siqueira JF Jr, Rôças IN. Clinical implications and microbiology of bacterial persistence after treatment procedures. J Endod. 2008 Nov;34(11):1291-1301.e3. https://doi.org/10.1016/i.joen.2008.07.028 P

138. Siqueira JF Jr, Alves FR, Versiani MA, Rôças IN, Almeida BM, Neves MA et al. Correlative bacteriologic and microcomputed tomographic analysis of mandibular molar mesial canals prepared by self-adjusting file, reciproc, and twisted file systems. J Endod. 2013 Aug;39(8):1044-50. https://doi.org/10.1016/i.joen.2013.04.034

139. American Association of Endodontics.. Glossary of endodontic terms. 9th ed. Chicago: American Association of Endodontics; 2016.

140. Gambill JM, Alder M, Rio CE. Comparison of nickeltitanium and stainless steel hand-file instrumentation using computed tomography. J Endod. 1996 Jul;22(7):369-75. https://doi.org/10.1016/S0099-2399(96)80221-4 
141. Shah DY, Wadekar SI, Dadpe AM, Jadhav GR, Choudhary LJ, Kalra DD. Canal transportation and centering ability of protaper and self-adjusting file system in long oval canals: An ex-vivo cone-beam computed tomography analysis. J Conserv Dent. 2017 Mar-Apr;20(2):105-9. https://doi. org/10.4103/0972-0707.212234

142. Kandaswamy D, Venkateshbabu N, Porkodi I, Pradeep G. Canal-centering ability: an endodontic challenge. J Conserv Dent. 2009 Jan;12(1):3-9. https://doi.org/10.4103/09720707.53334

143. Peters $O$, Barbakow F. Apical transportation revisited or 'where did the K-file go'? Int Endod J. 1999 Mar;32(2):131-7. Available from: http:// www.ncbi.nlm.nih.gov/pubmed/10371909 https://doi.org/10.1046/i.1365-2591.1999.00179.x

144. Peters OA, Laib A, Rüegsegger P, Barbakow $F$. Three-dimensional analysis of root canal geometry by high-resolution computed tomography. J Dent Res. 2000 Jun;79(6):1405-9. https://doi.org/10.1177/00220345000790060901

145. Musikant BL, Cohen BI, Deutsch AS. Comparison instrumentation reamers and files versus a flatsided design of conventional noninterrupted, flatsided design. J Endod. 2004 Feb;30(2):107-9. https://doi.org/10.1097/00004770-200402000-00011

146. Pedullà E, Corsentino G, Ambu E, Roval F, Campedelli, Rapisarda $S$ et al. Influence of continuous rotation or reciprocation of Optimum Torque Reverse motion on cyclic fatigue resistance of nickel-titanium rotary instruments. Int Endod J. 2017. https://doi.org/10.1111/iej.12769

147. Sahu G, Consul S, Nandakishore K, Shubhashini N, Geeta I, Idris M. Rotary endodontics or reciprocating endodontics: which is new and which is true? J Heal Sci Researc. 2016;7(2):51-7.

148. Schäfer E, Florek H. Efficiency of rotary nickeltitanium K3 instruments compared with stainless steel hand K-Flexofile. Part 1. Shaping ability in simulated curved canals. Int Endod J. 2003 Mar;36(3):199-207. https://doi.org/10.1046/j.1365-2591.2003.00643.x

149. Pasternak-Júnior B, Sousa-Neto MD, Silva RG. Canal transportation and centring ability of RaCe rotary instruments. Int Endod J. 2009 Jun;42(6):499-506. https://doi.org/10.1111/i.1365-2591.2008.01536.x

150. Siqueira JF Jr, Alves FR, Almeida BM, Oliveira JC, Rôças IN. Ability of chemomechanical preparation with either rotary instruments or self-adjusting file to disinfect oval- shaped root canals. J Endod. 2010 Nov;36(11):1860-5. https://doi.org/10.1016/i.joen.2010.08.001

151. Setzer FC, Kwon TK, Karabucak B. Comparison of apical transportation between two rotary file systems and two hybrid rotary instrumentation sequences. J Endod. 2010 Jul;36(7):1226-9. https://doi.org/10.1016/i.joen.2010.03.011

152. Iqbal MK, Gartenberg J, Kratchman SI, Karabucak B, Bui B. The clinical significance and management of apical accessory canals in maxillary central incisors. J Am Dent Assoc. 2005;136(3):331-5-81. https://doi.org/10.14219/jada.archive.2005.0173

153. Alves FR, Andrade-Junior CV, Marceliano-Alves MF, Pérez $A R$, Rôças IN, Versiani MA et al. Adjunctive steps for disinfection of the mandibular molar root canal system: a correlative bacteriologic, micro-computed tomography, and cryopulverization approach. J Endod. 2016 Nov;42(11):166772. https://doi.org/10.1016/i.joen.2016.08.003

154. Dietrich MA, Kirkpatrick TC, Yaccino JM. In vitro canal and isthmus debris removal of the self-adjusting file, $\mathrm{K} 3$, and WaveOne files in the mesial root of human mandibular molars. J Endod. 2012 Aug;38(8):1140-4. https://doi.org/10.1016/i.joen.2012.05.007

155. Myers GL, Montgomery S. A comparison of weights of debris extruded apically by conventional filing and Canal Master techniques. J Endod. 1991 Jun;17(6):275-9. https://doi.org/10.1016/S0099-2399(06)81866-2

156. Schäfer E, Nelius B, Bürklein S. A comparative evaluation of gutta-percha filled areas in curved root canals obturated with different techniques. Clin Oral Investig. 2012 Feb;16(1):225 30. https://doi.org/10.1007/s00784-011-0509-z

157. Machado ME, Sapia LA, Cai S, Martins GH, Nabeshima CK. Comparison of two rotary systems in root canal preparation regarding disinfection. J Endod. 2010 Jul;36(7):1238-40. https://doi.org/10.1016/i.joen.2010.03.012

158. Machado MEL, Nabeshima CK, Leonardo MFP, Reis FAS, Britto MLB, Cai S. Influence of reciprocating singlefile and rotary instrumentation on bacterial reduction on infected root canals. Int Endod J. 2013;46(11):1083-7. https://doi.org/10.1111/iej.12108

159. Nabeshima CK, Caballero-Flores H, Cai S, Aranguren J, Borges Britto ML, Machado ME. Bacterial removal promoted by 2 single-file systems: wave one and one shape. J Endod. 2014 Dec;40(12):1995-8. https://doi.org/10.1016/i.joen.2014.07.024 